\title{
Spatial variation and risk assessment of trace metals in water and sediment of the Mekong Delta
}

\author{
Emilie Strady $\underline{a}, \underline{b}, \underline{*}$, , Quoc Tuc Dinh $\underline{b}, \underline{c}$, Julien Ne' mery $\underline{a}, \underline{b}$, Thanh Nho Nguyen $\underline{\mathrm{d}}$,

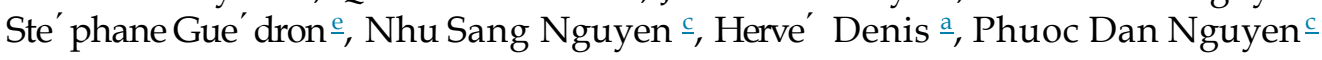 \\ a Univ. Grenoble Alpes, CNRS, IRD, Grenoble INP, IGE, F-38000 Grenoble, France \\ b CARE-HCMUT, Ho Chi Minh City, Viet Nam \\ ${ }^{c}$ Faculty of Environment, HCMUT, Ho Chi Minh City, Viet Nam \\ ${ }^{\mathrm{d}}$ Faculty of Chemistry, University of Sciences, Ho Chi Minh City, Viet Nam \\ e Univ. Grenoble Alpes, CNRS, IRD, ISTerre, F-38000 Grenoble, France
}

\section{h ig h l ig h t s}

- Trace metal transportation are controlled by SPM concentrations.

- Dissolved trace metal distribution vary in the salinity gradient.

- Ecotoxicological indexes in surface sediments show low to medium contamination.

\section{a $\mathrm{r}$ t i c l e i n f o}

\section{Article history:}

Received 29 November 2016

Received in revised form

23 March 2017

Accepted 26 March 2017

Available online 27 March 2017

\section{Keywords:}

Mekong Delta

Trace metals

Ecotoxicological index

Tropical river

Estuary

\begin{abstract}
a b s t r a c t
The Mekong Delta, is home to 17 million inhabitants and faces numerous challenges relating to climate change, environmental degradation and water issues. In this study, we assess trace metals concentrations $(\mathrm{Al}, \mathrm{V}, \mathrm{Cr}, \mathrm{Mn}, \mathrm{Fe}, \mathrm{Co}, \mathrm{Ni}, \mathrm{Cu}, \mathrm{Zn}, \mathrm{As}, \mathrm{Mo}, \mathrm{Cd}, \mathrm{Hg}, \mathrm{Pb}$ ) in the water, suspended particulate matter and surface sediments of the Tien River, the Northern branch of the Mekong Delta, during both dry and rainy seasons. Metal concentrations in the dissolved and suspended particle phases remain in the low concentration range of the main Asian Tropical River. During transportation in the riverine part, we evidenced that $\mathrm{V}$, $\mathrm{Cr}, \mathrm{Co}, \mathrm{As}$ and $\mathrm{Pb}$ are dominant in the particulate phase while $\mathrm{Mo}$, Ni and $\mathrm{Cu}$ dominate in the dissolved fraction. In the salinity gradient, dissolved U, V, Mo exhibit conservative behaviour while Ni, Cu, As, Co and $\mathrm{Cd}$ showed additive behaviour suggesting desorption processes. In the surface sediment, metal concentrations are controlled by the particle-size, POC contents and Fe, $\mathrm{Al}$ and Mn e oxy(hydr)oxides. Calculated Enrichment Factor and Geoaccumulation Index evidenced As enrichment while the calculated mean effect range median quotients evidenced a low to medium ecotoxicological potential effects range in the surface sediments.
\end{abstract}

\section{Introduction}

Deltas and estuaries play a major role in material and element transport from river to ocean and on biogeochemical cycles. The various physical and chemical gradients that occur in this mixing environment affect the partitioning, mobility and reactivity of elements such as nutrients and trace metals (e.g. Du Laing et al.,

\footnotetext{
* Corresponding author.Univ. Grenoble Alpes, CNRS, IRD, Grenoble INP, IGE, F38000 Grenoble, France.

E-mail address: emilie.strady@ird.fr(E. Strady).
}

2008; de Souza Machado et al., 2016; Garnier et al., 2010). Because of their persistence, toxicity and ability to accumulate in organisms, trace metals are major pollutants and are considered a high priority (i.e. European Water Framework Directive (Anonymous, 2000), US-EPA (40 CFR Part 423, Appendix A). Trace metals in aquatic environments originate mostly from natural erosion and soil leaching. They are also released by human activity such as industrial, domestic, urban and agricultural practices. Suspended particles are a key factor in contaminant transport from the continent to the ocean, making their quality assessment a major scientific concern (e.g. Apitz and Power, 2002). Understanding the processes controlling elemental transport and reactivity between 
the dissolved and particulate (both suspended and deposited sediments) phases in rivers and more particularly in estuaries is thus crucial to assess their impact in terms of contamination and ecotoxicological risks.

The Mekong River is the longest River in Southeast Asia with a total length of $4800 \mathrm{~km}$ and a drainage basin of $795,000 \mathrm{~km}^{2}$. It originates in the Tibetan Plateau of western China and flows southward through China, Myanmar, Laos, Thailand, and Cambodia, before entering Vietnam through the Delta and then discharging into the South China Sea. The Mekong Delta is one of the world's largest deltas (39 $\left.000 \mathrm{~km}^{2}\right)$ and has a population of around 17 million people $(\underline{\mathrm{GSO}}, 2016)$. It is the principal area of rice production in Vietnam and its economy is largely reliant on agriculture (namely rice and fruit) and aquaculture (mainly shrimp and catfish). Despite recent intensification of agricultural and aquaculture activity as well as rapid urban growth, the Mekong Delta remains one of the poorest regions in Vietnam (Renaud and Künzer, 2012). The delta's natural and social systems face numerous challenges related to climate change, environmental degradation and water issues such as flooding, water pollution and access to water (Xue et al., 2011; Renaud and Künzer, 2012). Hydroelectric dams on the Mekong River and its tributaries have severely impacted the aquatic ecosystem's biodiversity (Campbell, 2012). Sediment supply to the delta and the ocean is also impacted, and estimates suggest that it retains about $32 \mathbf{e} 41$ million tons of sediment per year (Kummu et al., 2010). Indeed, before dam construction, the Mekong was one of the 10 largest sediment suppliers to the world's oceans with an annual sediment flux estimated at around 160 million tons (Milliman and Meade, 1983; Milliman and Ren, 1995). Numerous dams are currently under construction or in the planning stages on the main stream and in the tributaries, increasing the vulnerability of the Mekong River. The Mekong Delta river quality is also threatened by the development of intensive agricultural and aquaculture activity and the release of pesticides (Toan et al., 2013), antibiotics (Giang et al., 2015), nutrients and trace metals (Wilbers et al., 2014).

Information on trace metal risk assessment in the Mekong Delta's waters and surface sediments is not readily available (e.g. Cenci and Martin, 2004; Noh et al., 2013; Wilbers et al., 2014) and studies that are available have mainly focused on arsenic groundwater contamination issues and consequences to population health (Berg et al., 2007; Buschmann et al., 2008; Hoang et al., 2010). Thus, considering the environmental challenges that are facing the Mekong Delta, the purpose of this study is to evaluate trace element contamination (Al, V, Cr, Mn, Fe, Co, Ni, Cu, Zn, As, Mo, Cd, Hg, Pb, U) of the Tien River, Mekong Delta, Vietnam. Two snapshot campaigns were performed along the Tien River during the contrasted seasons (dry and rainy seasons). The objectives were (i) to get an inventory of dissolved and particulate polymetallic concentrations which affect the quality of the river, (ii) to identify the fate of metal distribution in the water column and sediment and the factors controlling their partitioning, and (iii) to provide a risk assessment of surface sediments based on geochemical and ecotoxicological indexes.

\section{Material and methods}

\subsection{The Tien River, Mekong Delta, Vietnam}

The Mekong Delta begins in Phnom Penh, Cambodia, where the river divides into its two main branches, the Mekong and the Bassac, which are respectively subdivided into six and three branches, the Tien River being the northern branch of the Delta (Fig. 1, $150 \mathrm{~km}$ long, $450 \mathbf{e} 2250 \mathrm{~m}$ width, up to $10 \mathrm{~m}$ depth). The Mekong Delta is composed of Holocene alluvial sediments of

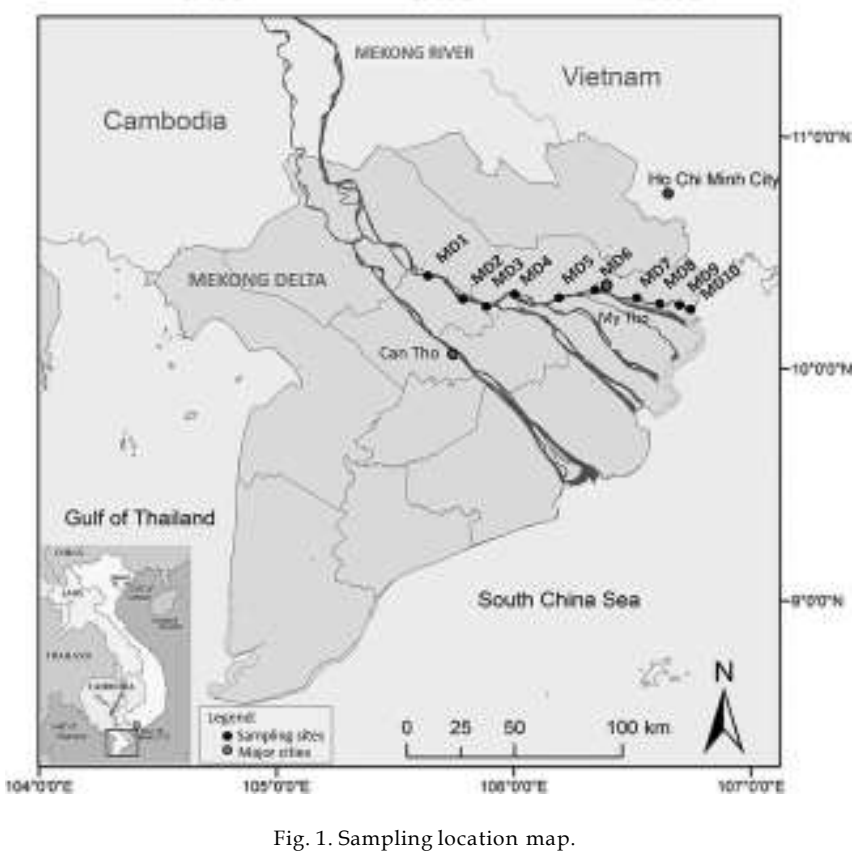

marine and fluvial origin that were rapidly deposited beginning 8000 year BP (Nguyen et al., 2000; Xue et al., 2011). The climate is monsoonal humid and tropical, with average temperatures of $27 \mathbf{e} 30{ }^{\circ} \mathrm{C}$. The rainy season (approximately $80 \%$ of the annual rainfall) lasts from May to October. Accordingly, the Mekong River discharge reaches a minimum in AprileMay and a maximum in SeptembereOctober in the lower Mekong (Xue et al., 2012) and the same is true for the Bassac River where the river discharge fluctuates from $200 \mathrm{~m}^{3} \mathrm{~s}^{-1}$ to $7000 \mathrm{~m}^{3} \mathrm{~s}^{-1}$ respectively (Loisel et al. 2014).

\subsection{Sampling and handling}

Two snapshot campaigns were conducted along the Tien River during dry and wet seasons, in March and October 2013, respectively. At each site (Table 1a), temperature, $\mathrm{pH}$, dissolved oxygen, conductivity and salinity were immediately measured in situ using a multi parameter probe (WTW $3420^{\circledR}$ ). Then, water was sampled at $10 \mathbf{e} 50 \mathrm{~cm}$ below surface using a Niskin non-metallic water sampling bottle (General Oceanic ${ }^{\circledR}$ ) and stored in 5L PE bottle. All filtered and unfiltered samples were stored in a cooler $\left(\sim 4{ }^{\circ} \mathrm{C}\right)$ until being brought back to the laboratory. A first filtration was performed on glass microfiber filter $\left(0.7 \mathrm{~mm} \mathrm{GF} / \mathrm{F}\right.$ Whatman ${ }^{\circledR}$, preweighed and preheated at $500{ }^{\circ} \mathrm{C}$ ). The filtrate was stored in a $60 \mathrm{ml}$ bottle and kept at $-18^{\circ} \mathrm{C}$ for analyses of dissolved nutrient while filters, used for determination of suspended particulate matter (SPM) and particulate organic carbon (POC) concentrations, were dried at $50{ }^{\circ} \mathrm{C}$, then weighed and stored at room temperature. A second filtration was realized on pre-weighed PTFE filters $(0.20$ $\mathrm{mm}$ Omnipore ${ }^{\circledR}$ ) for analysis of particulate and dissolved trace metals. After filtration, the filtrate was acidified (Normapur $\mathrm{HNO}_{3}$ $2 \% \mathrm{v} / \mathrm{v}$ ) and stored in a $30 \mathrm{ml}$ acid pre-cleaned PP bottle (Normapur $\mathrm{HNO}_{3} 10 \%$ v/v) at $4{ }^{\circ} \mathrm{C}$ while the filters were kept in sterile plastic petri dishes at $-18^{\circ} \mathrm{C}$, then freeze-dried, weighed and stored in the plastic petri dishes. To prevent contamination during collection and handling, all equipment was cleaned and we wrapped each subsample individually in two polyethylene bags. Surface sediments were collected at each site using a Shipek sediment grab sampler, immediately stored in PE bags at $-18^{\circ} \mathrm{C}$ and, freeze-dried. 
Table $1 \mathrm{a}$

Location of sampling site: GPS coordinates and main characteristics.

\begin{tabular}{|c|c|c|c|c|}
\hline Sampling site & Coordinates & & City & Activity \\
\hline MD-1 & $\mathrm{N} 10^{\circ} 24^{0} 51.0^{00}$ & $\mathrm{E} 105^{\circ} 39^{0} 11.8^{00}$ & Cao Lanh City, 110000 inhabitants & agriculture: rice, fruit; industrial activity \\
\hline MD-2 & $\mathrm{N} 10^{\circ} 17^{0} 55.7^{00}$ & $\mathrm{E} 105^{\circ} 46^{0} 06.4^{00}$ & Sa Dec City, 160000 inhabitants & agriculture: fruit \\
\hline MD-3 & $\mathrm{N} 10^{\circ} 16^{0} 38.3^{00}$ & $\mathrm{E} 105^{\circ} 54^{0} 24.5^{00}$ & My Thuan City, 160000 inhabitants & agriculture: fruit; industrial activity \\
\hline MD-4 & $\mathrm{N} 10^{\circ} 19^{0} 09.2^{00}$ & $\mathrm{E} 106^{\circ} 01^{0} 12.3^{00}$ & Cai Be City, 260000 inhabitants & agriculture: fruit \\
\hline MD-5 & $\mathrm{N} 10^{\circ} 18^{0} 57.0^{00}$ & $\mathrm{E} 106^{\circ} 12^{0} 02.0^{00}$ & Rural area & agriculture: rice, fruit \\
\hline MD-6 & $\mathrm{N} 10^{\circ} 20^{0} 53.4^{00}$ & $\mathrm{E} 106^{\circ} 21^{0} 02.6^{00}$ & My Tho City, 230000 inhabitants & agriculture: fruit; industrial activity \\
\hline MD-7 & $\mathrm{N} 10^{\circ} 18^{0} 35.8^{00}$ & $\mathrm{E} 106^{\circ} 30^{0} 17.9^{00}$ & Rural area & agriculture: rice, fruit; aquaculture: fish \\
\hline MD-8 & $\mathrm{N} 10^{\circ} 17^{0} 11.6^{00}$ & $\mathrm{E} 106^{\circ} 34^{0} 56.1^{00}$ & Rural area & agriculture: rice, fruit; aquaculture: shrimp \\
\hline MD-9 & $\mathrm{N} 10^{\circ} 17^{0} 19.3^{00}$ & $\mathrm{E} 106^{\circ} 41^{0} 39.0^{00}$ & Rural area & agriculture: rice, fruit; aquaculture: shrimp \\
\hline MD-10 & $\mathrm{N} 10^{\circ} 15^{0} 36.8^{00}$ & $\mathrm{E} 106^{\circ} 45^{0} 19.0^{00}$ & Rural area & agriculture: rice, fruit; aquaculture: shrimp \\
\hline
\end{tabular}

\subsection{Laboratory analyses}

\subsubsection{Trace metal analyses}

Particulate trace metals on PTFE filters (MetalsPM) and representative sub-samples of surface sediments (Metal $\mathrm{SED} ; 100 \mathrm{mg}$ of dried, powdered and homogenized material) were analyzed by a microwave total extractable acid digestion (NovaWave SCP Sciences $^{\circledR}$, IGE-OSUG Laboratory, Grenoble, France; $\mathrm{HCl}, \mathrm{HNO}_{3}, \mathrm{HF}$; Trace Metal grade Fisher ${ }^{\circledR}$ ). The protocol is based on the digestion method USEPA 3052 and is fully described in Strady et al. (2017). Trace metal concentrations ( $\mathrm{V}, \mathrm{Cr}, \mathrm{Co}, \mathrm{Ni}, \mathrm{Cu}, \mathrm{Zn}, \mathrm{As}, \mathrm{Mo}, \mathrm{Cd}, \mathrm{Pb}, \mathrm{U}$ ) were measured by ICP-MS (Elan DRC II Perkin Elmer, TERA Environment Laboratory Fuveau France) while $\mathrm{Al}, \mathrm{Mn}$ and Fe concentrations were measured by ICP-AES (Varian 720 ES, ISTerre-OSUG Laboratory, Grenoble, France) using external calibration for both cases. Total Hg concentrations in sediments THgSED were determined by atomic absorption spectrophotometry after dry mineralization and gold amalgamation by using an automatic mercury analyzer (Altec, Model AMA 254 ISTerre-OSUG Laboratory, Grenoble, France) (Gué dron et al., 2009; Strady et al., 2017). Metal concentrations were directly measured by ICP-MS (Elan DRC II Perkin Elmer) using external calibration. When the sample salinity was up to 1, dissolved trace metals were determined by Kinetic Energy Discrimination -Argon Gas Dilution (KED-AGD mode) with the Thermo Scientific iCAPQ ICP-MS (Plateforme AETEHydroSciences/OSU OREME, Montpellier, France) using an added on-line internal solution (Sc, Ge, In and $\mathrm{Bi}$ ) to correct signal drifts. The analytical quality assurance of particulate measurements was assured by analyzing certified reference materials. Accuracy was V: 6\%; Cr: $-6 \%$; Co: $7 \%$; Ni: $-2 \%$; Cu: $-6 \%$; Zn: $30 \%$; As: $1 \%$; Mo: $-3 \%$, Cd: $-13 \%, \mathrm{~Pb}:-8 \%, \mathrm{Hg}: 9 \%$ for GBW-07323 (n $1 / 45)$ and $\mathrm{V}: 1 \%$; Cr: $-6 \%$; Co: $-7 \%$; Ni: $-13 \%$; Cu: $-9 \%$; Zn: 29\%; As: $-5 \%$; Mo: $-3 \%$, Cd: $2 \%, \mathrm{~Pb}:-9 \%, \mathrm{Hg}: 5 \%$ for MESS-3 (n 1/4 4). Precision was lower than $8 \%$ for all elements and both GBW-07323 and MESS-3.

\subsubsection{Particulate organic carbon analyses}

Acombustion infrared detection technique using a LECOCS-125 analyzer (EPOC Laboratory, Talence, France) with 5\% precision was used to determine POC concentrations. Contents of POC are expressed as a percentage of the dry weight of SPM or sediment, abbreviated as POC\%.

\subsubsection{Orthophosphates, nitrates and ammonium analyses}

Orthophosphates ( $\left.\mathrm{P}_{-} \mathrm{PO}_{4}\right)$ were analyzed using the ascorbic acid-molybdate blue method developed by Murphy and Riley (1962) prior to spectrophotometric measurements. Ammonium $\left(\mathrm{N}-\mathrm{NH}_{4}\right)$ was analyzed directly on site using the standard colorimetric method ( $\underline{\text { APHA, 1995) }})$ and Hach Lange photolab. Nitrate $(\mathrm{N}-$ $\mathrm{NO}_{3}$ ) was measured by ion chromatography (A-732 Metrohm $^{\circledR}$ separation-center based system using anion column Metrosep ASUPP-5-150 ${ }^{\circledR}$ ). Precision was $10 \%$ for all dissolved nutrient analysis.

\subsubsection{Grain size distribution analyses}

Grain size distribution was measured on bulk sub-samples using a laser diffraction sizer after a $3 \mathrm{~min}$ ultrasonic agitation (Malvern Mastersizer 2000, IGE-OSUG Laboratory, Grenoble, France).

\subsection{Geochemical and ecotoxicological indexes}

\subsubsection{Enrichment factor}

Assessment of the metal enrichment degree in sediments was undertaken using the enrichment factor (EF). The index allows differentiating natural geochemical background to anthropogenic inputs (Zhang and Liu, 2002). The enrichment factor is defined as the ratio of $\mathrm{Al}$ normalized metal concentrations in sediments over Al normalized ratio in a geochemical background reference. Normalization to $\mathrm{Al}$ is used to compensate natural variability due to grain-size variations (e.g. mineral composition) and to detect any anthropogenic metal contributions (Loring, 1991; Chapman and Wang, 2001). Zhang and Liu (2002) defined that an EF value between 0.5 and 1.5 suggests natural weathering processes while a value of EF $>1.5$ suggests trace metals being delivered from noncrustal materials corresponding to enrichment from anthropogenic sources. More precisely, Birth (2003) defined that $1.5<\mathrm{EF}<3$ is minor enrichment, $3<\mathrm{EF}<5$ is moderate enrichment, $5<\mathrm{EF}<10$ is moderately severe enrichment, $10<\mathrm{EF}<25$ is severe enrichment, $25<\mathrm{EF}<50$ is very severe enrichment, and finally that $\mathrm{EF}$ $>50$ is extremely severe enrichment.

\subsubsection{Geoaccumulation Index (Igeo)}

The degree of metal enrichment was also assessed using the Geoaccumulation Index (Igeo, Müller, 1979) originally defined for metal concentrations in the $<2 \mathrm{~mm}$ fraction with respect to the background value Bn as a 'pre-civilisation' value for the study area. The Igeo calculation is based on the following formula:

Igeo $1 / 4 \log _{2} \frac{\mathrm{Cn}}{1: 5^{*} B n}$

where $C_{n}$ is the measured concentration in the sediment for metal $n, \mathrm{~B}_{n}$ is the background value for the metal $n$, and factor 1.5 is used because of possible variations in background data due to lithological variations. The geoaccumulation Index includes seven grades: Igeo $\leq 0$ Uncontaminated; $0<$ Igeo $<1$ uncontaminated to moderately contaminated; $1<$ Igeo $<2$ moderately contaminated; $2<$ Igeo $<3$ moderately to strongly contaminated; $3<$ Igeo $<4$ strongly contaminated; $4<$ Igeo $<5$ strongly to extremely contaminated; $5<$ Igeo extremely contaminated.

\subsubsection{Sediment quality guideline}

A sediment quality guideline (SQG) has been developed for singular ecosystems with freshwater or marine sediments. In marine ecosystems, the mean Effect Range Median quotients (m-ERM- 
q) is a pollutant-specific index from the SQG obtained in laboratory experiments using amphipod organisms (Long et al., 1998). It takes into account mixtures of contaminants, including trace metals, present in sediment samples, and provides a management tool for assessing sediment quality in terms of adverse biological effects. The m-ERM-q calculation is based on:

$m \rightarrow E R M \rightarrow q^{1 / 4} \frac{P_{n}^{n} \partial C_{i}=E R M P}{n}$

where $C_{\mathrm{i}}$ is the concentration of the pollutant $i$ in the sample, ERMi is the experimentally defined effect concentration for the pollutant $i$ and $n$ is the number of studied pollutants $i$. Four classes of toxicity probability for biota are then defined: low (m-ERM-q <0.1), lowmedium (m-ERM-q: 0.11e0.5), mediumehigh (m-ERM-q: $0.51 \mathbf{e} 1.5)$ and high priority sites (m-ERM-q >1.5) (Long et al., 1998). The m-ERM-q index is derived from the concept of effect range-low (ERL i.e.10th percentile of the effect dataset) and effect rangemedian (ERM i.e. $50^{\text {th }}$ percentile of the effect dataset) defined by Long et al. (1995) respectively as the concentrations below which adverse effects are not expected to occur, above which adverse effects are expected to occur.

In freshwater ecosystems, MacDonald et al. (2000) evaluated a consensus-based SQG for 28 chemicals (i.e. metals, polycyclic aromatic hydrocarbons, polychlorinated biphenyls, and pesticides) and developed the threshold effect concentration (TEC) and probable effect concentration (PEC) indexes for freshwater sediment. The TEC was defined as the concentration below which adverse effects are not expected to occur and the PEC as the concentration above which adverse effects are expected to occur more often than not. Based on the mean Effect Range Median quotient (m-ERM-q; Long et al., 1998), a mean PEC quotient (m-PEC-q) was defined by MacDonald et al. (2000) as predicting the absence of toxicity if mean PEC quotient is lower than 0.5 and a high probability of sediment toxicity if the mean PEC quotient is higher than 0.5 .

\subsection{Statistical analysis}

The Pearson correlation coefficient matrix and one-way ANOVA at probability level $\mathrm{p}<0.05$ (to test seasonal effect) were performed using statistical package software (SPSS; version 23).

\section{Results \& discussion}

\subsection{River water mass characteristics}

Physico-chemical parameters vary along the river and between the seasons (Table 1b). The dry season is characterized by higher water temperature (approximately p2 ${ }^{\circ} \mathrm{C}$ ) and a saline water intrusion up to the MD7 site (the intrusion being downstream during rainy season). The $\mathrm{pH}$ and $\mathrm{DO}$ values vary with opposite seasonal trends: $\mathrm{pH}$ being more acidic during the rainy season whereas water is less oxygenated during the dry season. The Tien River acidification is closely related to the leaching of the surrounding acid sulfate soils during rainy seasons (Minh et al., 1997) while the decreasing oxygenation during the dry season could be the result of enhanced organic matter degradation along the river network (Trinh et al., 2012). The local DO decrease observed at MD6 during both seasons is the likely result of direct domestic and urban discharges from My Tho City (230 000 inhabitants; Table 1a). During the dry season, the $\mathrm{P}-\mathrm{PO}_{4}$ concentrations are quite low but increases locally in nearby urban centres (between MD-2 and MD4; Table 1a, 2) while the $\mathrm{N}-\mathrm{NO}_{3}$ concentrations are likely the result of intense agricultural activity along this river (Table 2). In the estuarine environment, (MD-8 to MD-10) $\mathrm{N}_{-} \mathrm{NH}_{4}$ concentrations
(Table 2) increased two fold and could be related to intense aquaculture activity (Table 1a). During the rainy season, different distributions are observed with lower nutrient concentrations highlighting the strong dilution capacity of the Mekong River. Despite significant progress in the development of the wastewater management sector in Vietnam, $60 \%$ of urban wastewater is connected to sewerage and only $10 \%$ of this collected wastewater is treated (World Bank, 2013). Specifically in the Mekong Delta, water quality management is an urgent problem with regards the multiple sources of pollution including domestic, urban, agricultural, industrial and aquaculture sources (Waibel et al., 2012). A dramatic rise in nutrient concentrations has also been observed on a global scale in the last decade, in response to land use changes and urban development, in rivers from South-East Asia countries such as in the lower Mekong basin in Laos (Li and Bush, 2015), the Red River watershed in Northern Vietnam (Garnier et al., 2015), and in the Yangtze River in China (Li et al., 2011).

In the Tien River, SPM concentrations are low during both seasons (Table 3 ) and in a similar range as previously reported by $\underline{\text { Noh }}$ et al. (2013). Higher concentrations were measured during the rainy seasons and are related to enhanced SPM transfer in the Mekong watershed (Loisel et al., 2014). During the dry season, the low SPM concentrations increased sharply in the brackish zone (Table 3) suggesting estuarine flocculation processes (Lefebvre et al., 2012). The POCSPM contents vary from $1.1 \%$ to $9.0 \%$ (Table 3 ) and are in the same range as previously observed by Noh et al. (2013). During the dry season, the higher POCSPM contents measured in the riverine part support our hypothesis regarding the importance of local urban wastewater release into the river. Then, in the brackish zone, POCSPM decreased (i.e. MD6 to MD9; Table 3) suggesting both enhanced organic degradation processes in the estuarine water column and dilution of fluvial particles by organicdepleted resuspended sediment (Etcheber et al., 2007; Statham, 2012). During the rainy season, the low POCSPM content (mean of $1.3 \%$ ) associated with high SPM concentration levels (Table 3 ) is likely related to the terrigenous origin of the SPM. This minimum POCSPM value, defined as the terrigenous signature, can range from $0.5 \%$ in a very erodible watershed (e.g. in the Taiwan watershed; Kao and Liu, 1997) and up to 5\% in an equatorial forested watershed (e.g. the Congo River Coynel et al. (2005).

\subsection{Filtered and suspended particulate metal dynamics in the Tien River}

Filtered $\left(\mathrm{V}_{\mathrm{F}}, \mathrm{Cr}_{\mathrm{F}}, \mathrm{CoF}_{\mathrm{F}}, \mathrm{Ni}_{\mathrm{F}}, \mathrm{Cu}_{\mathrm{F}}, \mathrm{ZnF}_{\mathrm{F}}, \mathrm{As} \mathrm{F}, \mathrm{MoF}, \mathrm{Cd}_{\mathrm{F}}, \mathrm{Pb}_{\mathrm{F}}, \mathrm{U}_{\mathrm{F}}\right)$ and particulate (VSPM, CrspM, CospM, NispM, CuspM, ZnSPM, AsSpM, Mospm, $\left.\mathrm{Cd}_{\mathrm{SPM}}, \mathrm{Pb}_{\mathrm{SPM}}, \mathrm{Al}_{\mathrm{SPM}}, \mathrm{Fe}_{\mathrm{SPM}}, \mathrm{Mn}_{\mathrm{SPM}}\right)$ trace metal concentrations measured in the Tien River (Table 2; Table 3) are within the mean world rivers dissolved (Gaillardet et al., 2014) and particulate (Viers et al., 2009) values and in the same concentration range as previously reported in the Mekong Delta (Cenci and Martin, 2004) and in the Lower Mekong River (Gaillardet et al., 1999). In particular, As concentrations remain far below the concentrations previously reported in the Mekong Delta aquifers (Berg et al., 2007). The comparison to main Asian tropical rivers (Table 4) such as the Yangtze River Estuary (Yang et al., 2014), the Huanghe River Estuary (Wang et al., 2016a) and the Pearl River Estuary (Zhang and Liu, 2002; Zhang et al., 2013) demonstrates that the Mekong Delta is in the low range of both dissolved and particulate concentrations, confirming the previous statement of Cenci and Martin (2004) on the negligible anthropogenic metal inputs to this system. The $\mathrm{pH}$, DO and SPM concentrations have a limited effect on the dynamic of Metal $_{\mathrm{F}}$ concentrations $\left(\mathrm{r} 1 / 40.73, \mathrm{p}<0.01\right.$ level for $\mathrm{Ni}_{\mathrm{F}}$ and SPM only) and MetalsPM concentrations ( $\mathrm{r} 1 / 40.79$ and $\mathrm{r} 1 / 40.76, \mathrm{p}<0.01$ level for AlsPM and FesPM with SPM only). Accordingly, the metal 
Table $1 \mathrm{~b}$

Measured dissolved oxygen (DO), pH, temperature, conductivity, salinity and SPM concentrations in surface water, grain size distribution and modes of surface sediments at each sampling site during both dry and rainy seasons. (n.d.: not determined).

$\begin{array}{lllllll}\text { Sampling site } & \text { D.O. mg L } & \text { GH } & \mathrm{T}^{\circ} \mathrm{C} & \text { Conductivity } \mathrm{mS} \mathrm{cm}^{-1} & \text { Sal } & \text { Grain size distribution }\end{array}$

\begin{tabular}{|c|c|c|c|c|c|c|c|c|c|c|}
\hline & & & & & & & $\overline{\mathrm{D} 10}$ & D50 & D90 & mode \\
\hline \multirow[t]{10}{*}{ March dry season } & MD-1 & 4.82 & 7.82 & 31.8 & 0.216 & 0.1 & 2.4 & 12.6 & 48.5 & uni-modal \\
\hline & $\mathrm{MD}-2$ & 4.9 & 7.61 & & 0.207 & 0.1 & 5.6 & 49.3 & 117.0 & uni-modal \\
\hline & MD-3 & 5.02 & 7.05 & 30.1 & 0.21 & 0.1 & 4.0 & 47.2 & 171.5 & bi-modal \\
\hline & $\mathrm{MD}-4$ & 5.06 & 7.44 & 30.2 & 0.219 & 0.1 & 2.9 & 39.8 & 161.4 & bi-modal \\
\hline & MD-5 & 4.67 & 7.59 & & 0.212 & 0.1 & 4.0 & 42.3 & 310.8 & bi-modal \\
\hline & MD-6 & 3.77 & 7.58 & 30.3 & 0.404 & 0.1 & 2.5 & 15.3 & 56.7 & uni-modal \\
\hline & MD-7 & 4.48 & 7.68 & 30.5 & 3.4 & 1.7 & 2.5 & 13.8 & 56.5 & uni-modal \\
\hline & MD-8 & 4.31 & 7.8 & 30.6 & 8.33 & 4.7 & 2.6 & 15.9 & 143.8 & bi-modal \\
\hline & MD-9 & 6 & 7.91 & n.d. & 18.9 & 11.3 & 1.7 & 6.4 & 24.4 & uni-modal \\
\hline & MD-10 & 6 & 8.25 & 30.2 & 30.7 & 19 & 2.2 & 16.3 & 97.9 & bi-modal \\
\hline \multirow[t]{5}{*}{ October rainy season } & $\mathrm{MD}-4$ & 4.88 & 7.22 & 27.8 & 80 & 0 & 2.3 & 11.9 & 46.2 & uni-modal \\
\hline & MD-5 & 5.31 & 7.1 & 27.7 & 75.5 & 0 & 1.7 & 7.6 & 31.9 & uni-modal \\
\hline & MD-6 & 4.63 & 6.95 & 27.9 & 82.5 & 0 & 2.7 & 16.4 & 57.8 & uni-modal \\
\hline & MD-7 & 5.41 & 7.1 & 27.8 & 84.7 & 0 & 1.5 & 6.5 & 21.2 & uni-modal \\
\hline & MD-10 & 6.6 & 7.4 & 27.9 & 3470 & 1.8 & 2.1 & 10.7 & 58.0 & uni-modal \\
\hline
\end{tabular}

Table 2

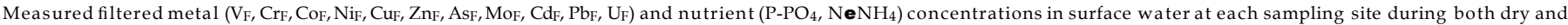
rainy seasons. (n.d.: not determined).

\begin{tabular}{|c|c|c|c|c|c|c|c|c|c|c|c|c|c|c|c|}
\hline & Sites & $V_{F}$ & $\mathrm{CrF}_{\mathrm{F}}$ & $\mathrm{CoF}$ & $\mathrm{NiF}$ & $\mathrm{CuF}$ & $\mathrm{ZnF}$ & AsF & MoF & $\mathrm{CdF}$ & $\mathrm{PbF}$ & $U_{F}$ & $\mathrm{P}-\mathrm{PO}_{4}$ & $\mathrm{NeNH}_{4}$ & $\mathrm{NeNO}_{3}$ \\
\hline & units & $\mathrm{mg} \mathrm{L}^{-1}$ & $\mathrm{mg} \mathrm{L}^{-1}$ & $\mathrm{mgL}^{-1}$ & $\mathrm{mg} \mathrm{L}^{-1}$ & $\mathrm{mg} \mathrm{L}^{-1}$ & $\mathrm{mgL}^{-1}$ & $\mathrm{mg} \mathrm{L}^{-1}$ & $\mathrm{mg} \mathrm{L}^{-1}$ & $\mathrm{mg} \mathrm{L}^{-1}$ & $\mathrm{mgL}^{-1}$ & $\mathrm{mg} \mathrm{L}^{-1}$ & $\mathrm{mg} \mathrm{L}^{-1}$ & $\mathrm{mg} \mathrm{L}^{-1}$ & $\mathrm{mg} \mathrm{L}^{-1}$ \\
\hline \multirow[t]{10}{*}{ March dry season } & MD-1 & 1.37 & 0.092 & 0.061 & 0.46 & 0.63 & 11.8 & 1.63 & 0.35 & 0.005 & 0.041 & 0.38 & 0.02 & 0.06 & 1.5 \\
\hline & MD-2 & 1.32 & 0.066 & 0.042 & 0.62 & n.d. & 9.3 & 1.60 & 0.36 & 0.010 & 0.061 & 0.38 & 0.03 & 0.07 & 1.7 \\
\hline & MD-3 & 1.28 & 0.044 & 0.040 & 0.46 & 0.78 & 14.6 & 1.50 & 0.36 & 0.009 & 0.017 & 0.36 & 0.22 & 0.03 & 1.8 \\
\hline & MD-4 & 1.16 & 0.062 & 0.047 & 0.49 & 1.06 & 30.2 & 1.30 & 0.32 & 0.022 & 0.246 & 0.27 & 0.04 & 0.06 & 2.0 \\
\hline & MD-5 & 1.30 & 0.007 & 0.031 & 0.44 & 0.64 & 11.7 & 1.38 & 0.32 & 0.004 & 0.013 & 0.18 & 0.02 & 0.06 & 2.2 \\
\hline & MD-6 & 2.31 & 0.109 & 0.064 & 0.48 & 0.99 & 72.3 & 1.38 & 0.27 & 0.007 & 0.141 & 0.11 & 0.01 & 0.05 & 2.8 \\
\hline & MD-7 & n.d. & 0.978 & 0.067 & 0.70 & 0.99 & 7.1 & n.d. & 0.67 & 0.008 & 0.061 & 0.16 & 0.01 & 0.07 & 1.5 \\
\hline & MD-8 & 1.43 & 0.157 & 0.046 & 0.52 & 1.22 & 18.3 & 1.16 & 1.63 & 0.012 & 0.080 & 0.51 & 0.01 & 0.14 & 1.4 \\
\hline & MD-9 & 1.67 & 0.109 & 0.041 & 0.61 & 1.21 & 12.9 & 1.36 & 3.56 & 0.013 & 0.039 & 1.19 & 0.01 & 0.14 & n.d. \\
\hline & MD-10 & 1.95 & 0.138 & 0.038 & 0.73 & 1.41 & 32.2 & 1.47 & 6.37 & 0.024 & 0.035 & 2.04 & 0.01 & 0.16 & n.d. \\
\hline \multirow[t]{5}{*}{ October rainy season } & MD-4 & 1.41 & 0.059 & 0.476 & 3.26 & 2.90 & 29.9 & 0.93 & 0.12 & $<0.01$ & 0.804 & 0.05 & 0.01 & 0.07 & 0.2 \\
\hline & MD-5 & 1.38 & 0.035 & 0.524 & 2.22 & 0.96 & 37.4 & 0.88 & 0.52 & $<0.01$ & 0.116 & 0.04 & 0.01 & 0.03 & 0.2 \\
\hline & MD-6 & 1.34 & 0.313 & 1.298 & 3.10 & 1.09 & 9.9 & 0.84 & 0.13 & $<0.01$ & 0.017 & 0.04 & 0.02 & 0.03 & 0.2 \\
\hline & MD-7 & 1.28 & 0.071 & 0.442 & 2.30 & 0.96 & 20.5 & 0.77 & 0.13 & $<0.01$ & 0.063 & 0.05 & 0.01 & 0.02 & 0.2 \\
\hline & MD-10 & 1.47 & $<0.01$ & 1.332 & 3.73 & 3.56 & 4.9 & 2.57 & 0.39 & $<0.01$ & $<0.01$ & 0.09 & 0.01 & 0.02 & 0.2 \\
\hline
\end{tabular}

Table 3

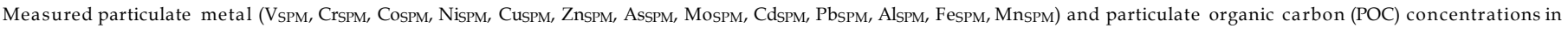
surface suspended sediment at each sampling site during both dry and rainy seasons. (n.d.: not determined).

\begin{tabular}{|c|c|c|c|c|c|c|c|c|c|c|c|c|c|c|c|c|}
\hline & \multirow{2}{*}{$\frac{\text { Sites }}{\text { units }}$} & \multirow{2}{*}{$\frac{\mathrm{V}_{\mathrm{SPM}}}{\mathrm{Mg} \mathrm{kg}^{-1}}$} & \multirow{2}{*}{$\frac{\mathrm{CrSPM}}{\mathrm{mg} \mathrm{kg}^{-1}}$} & \multirow{2}{*}{$\frac{\operatorname{Cospm}}{\mathrm{mg} \mathrm{kg}^{-1}}$} & \multirow{2}{*}{$\frac{\mathrm{NispM}}{\mathrm{mg} \mathrm{kg}^{-1}}$} & \multirow{2}{*}{$\frac{\text { Cuspm }}{\mathrm{mg} \mathrm{kg}^{-1}}$} & \multirow{2}{*}{$\frac{\mathrm{ZnSPM}_{\mathrm{SP}}}{\mathrm{mg} \mathrm{kg}^{-1}}$} & \multirow{2}{*}{$\frac{\text { AsspM }}{\mathrm{mg} \mathrm{kg}^{-1}}$} & \multirow{2}{*}{$\frac{\text { Mospm }}{\mathrm{mg} \mathrm{kg}^{-1}}$} & \multirow{2}{*}{$\frac{\mathrm{Cd} \text { SPM }}{\mathrm{mg} \mathrm{kg}^{-1}}$} & \multirow{2}{*}{$\frac{\mathrm{Pb} \text { SPM }}{\mathrm{mg} \mathrm{kg}^{-1}}$} & \multirow{2}{*}{$\frac{\mathrm{Al}_{\mathrm{SPM}}}{\mathrm{mg} \mathrm{kg}^{-1}}$} & \multirow{2}{*}{$\frac{\text { Fespm }}{\mathrm{mg} \mathrm{kg}^{-1}}$} & \multicolumn{3}{|c|}{ MnSPM POCSPM SPM } \\
\hline & & & & & & & & & & & & & & $\mathrm{mg} \mathrm{kg}^{-1}$ & $\%$ & $\mathrm{mg} \mathrm{L}^{-1}$ \\
\hline \multirow[t]{10}{*}{ March dry season } & MD-1 & n.d. & 18.0 & 6.8 & 12.1 & 13.9 & n.d. & n.d. & n.d. & n.d. & 16.0 & 12760 & 15105 & 675 & 9.0 & 7 \\
\hline & MD-2 & n.d. & 31.0 & 15.1 & 23.3 & 24.4 & 168 & n.d. & n.d. & n.d. & 27.8 & 21827 & 27909 & 1132 & 6.2 & 9 \\
\hline & MD-3 & n.d. & 27.8 & 13.3 & 20.2 & 21.1 & n.d. & n.d. & n.d. & n.d. & 24.0 & 20281 & 25035 & 1005 & 5.4 & 8 \\
\hline & MD-4 & n.d. & 36.2 & 15.7 & 24.7 & 92.1 & n.d. & n.d. & n.d. & n.d. & 29.0 & 23538 & 30528 & 753 & 3.5 & 11 \\
\hline & MD-5 & n.d. & 38.0 & 17.7 & 28.0 & 27.1 & 335 & n.d. & n.d. & n.d. & 36.6 & 29967 & 35531 & 678 & 5.5 & 11 \\
\hline & MD-6 & n.d. & 43.3 & 20.4 & 32.4 & 25.9 & 575 & n.d. & n.d. & n.d. & 27.9 & 34044 & 35902 & 569 & 1.7 & 43 \\
\hline & MD-7 & n.d. & 41.1 & 23.1 & 34.5 & 27.5 & 229 & n.d. & n.d. & n.d. & 30.9 & 29814 & 36704 & 1147 & 1.4 & 133 \\
\hline & MD-8 & n.d. & 39.7 & 18.5 & 29.2 & 33.6 & 92 & n.d. & n.d. & n.d. & 23.5 & 25199 & 31043 & 658 & 1.4 & 63 \\
\hline & MD-9 & n.d. & 61.6 & 28.2 & 43.4 & 31.0 & n.d. & n.d. & n.d. & n.d. & 39.0 & 39778 & 47598 & 1148 & 2.2 & 28 \\
\hline & MD-10 & n.d. & 41.6 & 18.4 & 29.8 & 29.0 & n.d. & n.d. & n.d. & n.d. & 25.2 & 26304 & 31389 & 721 & 2.7 & 30 \\
\hline \multirow[t]{5}{*}{ October rainy season } & $\mathrm{MD}-4$ & 125 & 23.4 & 14.1 & 27.3 & 41.0 & 147 & 21.6 & 0.45 & 0.17 & 32.7 & 99599 & 52591 & 297 & 1.1 & 154 \\
\hline & MD-5 & 122 & 38.9 & 14.3 & 33.0 & 40.6 & 144 & 22.1 & 0.58 & 0.17 & 33.4 & 94222 & 53578 & 490 & 1.2 & 171 \\
\hline & MD-6 & 136 & 34.8 & 16.4 & 34.4 & 47.1 & 287 & 24.3 & 0.61 & 0.28 & 37.0 & 106488 & 58989 & 552 & 1.3 & 148 \\
\hline & MD-7 & 121 & n.d. & 13.4 & 16.1 & 36.9 & 139 & 21.4 & 0.27 & 0.23 & 32.9 & 104556 & 54938 & 85 & 1.4 & 128 \\
\hline & MD-10 & 134 & 21.7 & 14.3 & 26.2 & 43.0 & 151 & 25.2 & 0.80 & $<\mathrm{LD}$ & 36.6 & 114618 & 58361 & 141 & 1.3 & 80 \\
\hline
\end{tabular}

partitioning in the river water column was firstly assessed by the partitioning coefficient $K_{d}$ defined as the ratio of MetalspM over Metal (Turner et al., 1993). The LogK $($ Table 5) are stable in the Tien River and do not present any significant variation with $\mathrm{pH}, \mathrm{DO}$ and SPM $(p>0.05)$. Consequently, the metal partitioning was assessed in a different way by taking into account the total concentration relative to the volume of water, expressed in $\mathrm{mg} \mathrm{L}^{-1}$ (i.e. the particulate concentrations were multiplied to the SPM concentrations and summed to the dissolved concentrations). The total concentrations expressed in $\mathrm{mLL}^{-1}$ (Fig. 2) vary through the Tien 
Table 4 Dissolved and particulate (in both suspended and deposited sediment) trace metal concentrations of main Asian tropical rivers. (References cited:Cenci and Martin, 2004; Yang et al., 2014; Wang et al., 2016b; Zhang et al., 2013; Zhang and Liu, 2002; Wang et al., 2015, 2017; Datta and Subramanian, 1998).

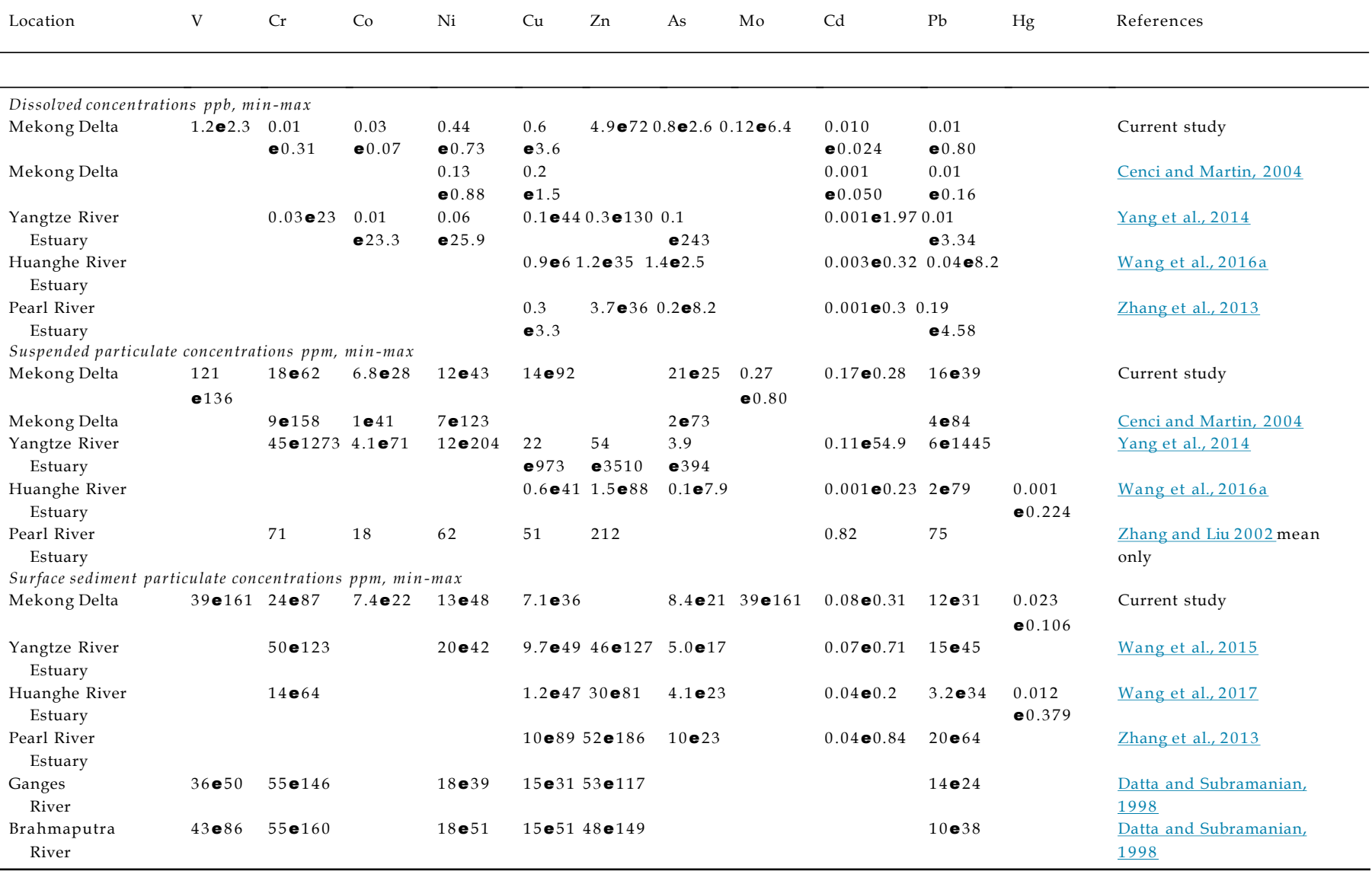

River and are higher during the wet season than during the dry season (ANOVA, $\mathrm{p}<0.01$ for $\mathrm{Cr}, \mathrm{Cu}$ and $\mathrm{Pb}$ ) suggesting enhanced metal load transport during the rainy season towards the ocean. Furthermore, particulate concentrations expressed in $\mathrm{mg} \mathrm{L}^{-1}$ vary from site to site and are closely related to SPM concentration variations (Fig. 2; $\mathrm{p}<0.01$ for total $\mathrm{V}, \mathrm{Cr}, \mathrm{Co}, \mathrm{Ni}, \mathrm{Cu}$ and $\mathrm{Pb}$ during both seasons). This pattern supports that SPM concentrations control the load of total metal concentrations in the Mekong Delta during both dry and wet seasons, as observed in the Yangtze River Estuary (Yang et al., 2014). Given the perspective of increased hydropower dam constructions on the main channel and its tributaries, the resulting decrease of sediment load will probably affect the trace metal load in the Mekong Delta. During transportation, the particulate phase is the dominant phase for $\mathrm{V}, \mathrm{Cr}, \mathrm{Co}$, As and $\mathrm{Pb}$ (Fig. 2) while the dissolved metal fraction dominates for $\mathrm{Mo}, \mathrm{Ni}$ and $\mathrm{Cu}$ in the riverine part, and only for Mo in the estuarine part (ig. 2). Dissolved metal concentrations vary along the estuarine salinity gradient (Table 2) resulting in high particulate-dissolved reactivity associated with physical, chemical and biological processes in the mixing zone (de Souza Machado et al., 2016). This reactivity can be approached by the mixing diagram (e.g. Liss, 1976; de Souza Machado et al., 2016), which reflects the concentration of an element over salinity between two endmembers: the river and the ocean (i.e. data from the South China Sea (Censi and Martin, 2004; Wang et al., 2012b; Wen et al., 2006) and from mean ocean values (Nozaki, 2001)). When the concentrations follow the theoretical dilution line between the two endmembers, the element is thus controlled by the physical mixing and its behaviour is defined as conservative. Such conservative behaviour is observed for $\mathrm{U}_{\mathrm{F}}, \mathrm{V}_{\mathrm{F}}$, and $\mathrm{MoF}_{\mathrm{F}}$ in the Tien River (Fig. 3; $\mathrm{p}<0.01$ for $\mathrm{U}_{\mathrm{F}}$ and MoF with salinity). In most estuaries that have been studied, $\mathrm{U}_{\mathrm{F}}$ behaves conservatively (Windom et al., 2000; reference within; Strady et al., 2009) while such behaviour is less usual for MoF and $V_{F}$ (e.g. in the Chao Phraya Estuary; Dalai et al., 2005). Both MoF and VF can be affected by intra-estuarine transformation processes like SPM or sediment sorption/desorption reactions and biological uptake as observed in the Gironde Estuary (Strady et al., 2009) and in the Taiwan Strait (Wang et al., 2016a). Thus, this non-conservative behaviour deriving from the theoretical dilution line (i.e. gain or loss of dissolved element), illustrates a higher reactivity between the dissolved and particulate phase (e.g. $\mathrm{SPM}$ or sediment). In the Tien River, gains of $\mathrm{Ni}_{\mathrm{F}}, \mathrm{Cu}_{\mathrm{F}}, \mathrm{As}_{\mathrm{F}}, \mathrm{CoF}$ and $\mathrm{Cd}_{\mathrm{F}}$ were observed (Fig. 3) suggesting intense desorption processes from particles occurring in the salinity gradient. This bell-shaped pattern is well documented for $\mathrm{Cd}_{\mathrm{F}}$ as a chloride-induced desorption from the suspended sediments and has been previously observed in the Mekong Delta (Cenci and Martin, 2004) and other estuaries like the Gironde Estuary (Kraepiel et al., 1997; Dabrin et al., 2009), the Pearl River (Wang et al., 2012a), the Saigon River (Strady et al., 2017) and the Huanghe River Estuary (Wang et al., 2016b). For CuF, even if a conservative behaviour is more usual and has been observed in the Mekong Delta (e.g. Cenci and Martin, 2004), in the Pearl River (Wang et al., 2012a) and in the Huanghe River estuary (Wang et al., 2016b), desorption from the reactive particles is the suggested explanation for the bell-shaped pattern observed in the Gironde Estuary (Kraepiel et al., 1997). In the Tien River, this hypothesis could explain the gain of $\mathrm{CuF}$ but the absence of significant correlation with SPM concentrations along the system $(p>0.05)$ and between $\operatorname{LogK}_{d}$ and salinity $(p>0.05)$ does not allow us to make any conclusions on $\mathrm{Cu}$ particle reactivity. Unlike previous measurements performed in the Mekong Delta (Cenci and 

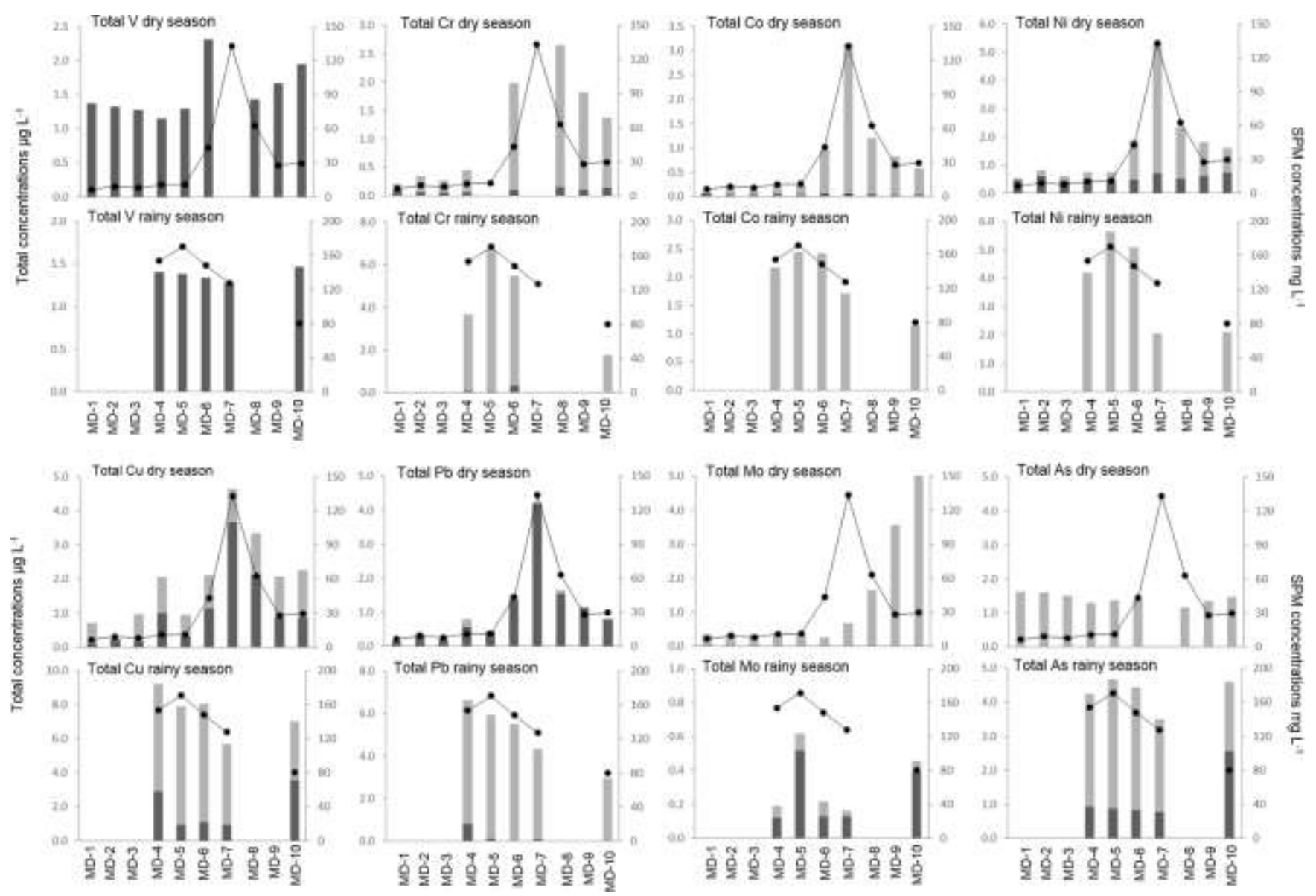

Fig. 2. Spatial variation of calculated total metal concentrations (sum of dissolved and particulate concentrations; $\mathrm{V}, \mathrm{Cr}, \mathrm{Co}, \mathrm{Ni}, \mathrm{Cu}, \mathrm{As}, \mathrm{Mo}, \mathrm{Pb}$ ) expressed in $\mathrm{mgL}{ }^{-1}$ and $\mathrm{SPM}$ concentrations expressed in $\mathrm{mg} \mathrm{L}^{-1}$ during both dry and rainy seasons.

Martin, 2004) and the Huanghe River estuary (Wang et al., 2016b), AsF and $\mathrm{Ni}_{\mathrm{F}}$ concentrations increase in the mid salinity range. In the case of As, the linear positive correlation ( $\mathrm{r} 1 / 40.79)$ observed between POCSPM and Asfduring the dry season suggests an Asrelease during organic degradation processes occurring in the estuary (Table $2 ; 3$ ). For $\mathrm{Ni}_{\mathrm{F}}$, the significant negative correlation with SPM concentrations $(\mathrm{r} 1 / 40.74, \mathrm{p}<0.01)$ suggests desorption from suspended particles along the salinity gradient. This is in accordance
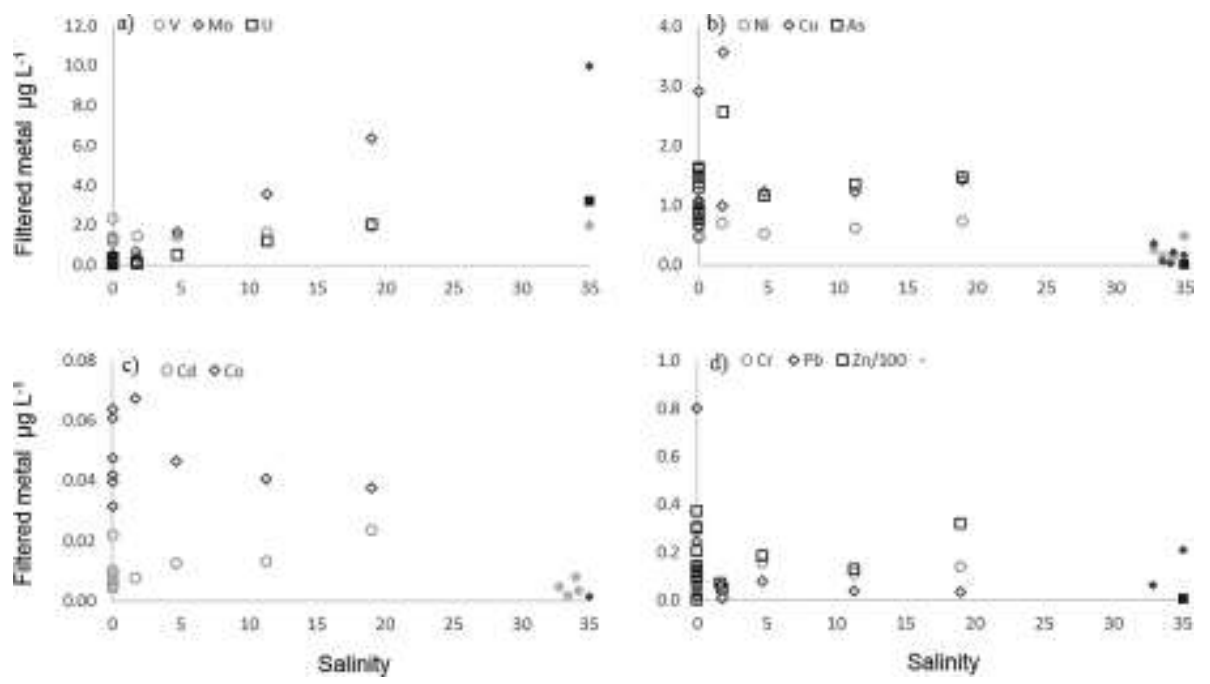

Fig. 3. Filtered metal concentrations along the salinity gradient a) V, Mo, U; b) Ni, Cu, As; c) Cd, Co; d) Cr, $\mathrm{Pb}$ and $\mathrm{Zn}$ (expressed as $\mathrm{Zn} / 100$ ) during both seasons. The marine endmember is characterized according to data from Wang et al., 2012b; Wen et al., 2006; Censi and Martin, 2004, Nozaki, 2001. 
with reported laboratory experiments and modelling of metal desorption kinetics which highlight $\mathrm{Ni}$ desorption from polluted riverine and estuarine sediments (Millward and Liu, 2003). However, the impact of desorption on observed non-conservative behaviour was minimized by the authors because of the low $\mathrm{Ni}$ kinetic desorption and the non-attempt of sorption equilibrium in a dynamic estuarine environment. Finally, concerning $\mathrm{Cr}_{\mathrm{F}}, \mathrm{Zn}_{\mathrm{F}}$ and $\mathrm{Pb}_{\mathrm{F}}$, the high variability of measured concentrations in the riverine part make it difficult to get a proper river endmember and therefore to determine the gain or loss of metal towards the ocean. Further investigation is needed to find the origin of this high variability, either from anthropogenic inputs (e.g. small localised industrial activity such as electronics, textiles and construction) or from acid sulfate soil leaching.

\subsection{Factors controlling metal distributions in the Tien River surface sediments}

The surface sediments of the Tien River present a grain size distribution dominated by silt classes $(54 \mathbf{e} 87 \%)$ and a median grain-size (D50) comprised between 6 and $49 \mathrm{~mm}$ (Table 1b). The grain size distributions varied from site to site and with seasons, without exhibiting a specific spatial pattern from the river to the coastline. The POCSED content ranges from 0.2 to $1.5 \%$ (Table 6). MetalsED concentrations measured in the Tien River (Table 6) are in the same range as previously observed in this system (Cenci and Martin, 2004; Noh et al., 2013) and are in the low concentration range of the main Asian Rivers (Table 4) such as the Yangtze River Estuary (Wang et al., 2015), the Huanghe River Estuary (Wang et al., 2017), the Pearl River Estuary (Zhang et al., 2013), the GangesBrahmaputra Rivers (Datta and Subramanian, 1998) and including the Saigon River (Strady et al., 2017). Cenci and Martin (2004)

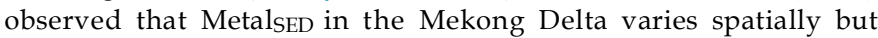
not seasonally. In this study, we observed the same pattern except for CusED and ZnSED (ANOVA, $p>0.05$ ).

In surface sediments, the Pearson correlation matrix applied to both seasons highlights positive correlations between the entire Metal $_{\text {SED }}$ set (including $\mathrm{Al}_{\mathrm{SED}}, \mathrm{Mn}_{\mathrm{SED}}$ and $\mathrm{Fe}_{\mathrm{SED}}$ ), and also between

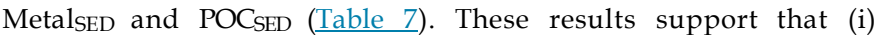
particle-size, (ii) POC content and/or (iii) $\mathrm{Fe}, \mathrm{Al}$ and $\mathrm{Mn}$ e oxy(hydr) oxides are the major carrier phases controlling the spatial distribution of particulate trace metals in this system. Firstly, the small sized particles' highly specific surface plays a major role in metal retention (e.g. Fo $€_{\text {rstner and Wittmann, 1979; Loring, 1991; Jung et }}$ al., 2014). Secondly, although POC SED content is low $(0.2 \% \mathbf{e}$ $1.5 \%$; Table 6), its strong correlation with HgSED, AsSED ( $\mathrm{r} 1 / 40.83$ and 0.84, for Hg and As respectively $\mathrm{p}<0.01$ Table 7) and COSED, CuSED
( $\mathrm{r} 1 / 40.76$ and $0.76 \mathrm{p}<0.01$ Table 7 ) suggest that organic matter is a major carrier for these elements, as it has been observed for $\mathrm{Cu}$ in the Saigon River sediments (Strady et al., 2017) and for $\mathrm{Hg}$ in the Lower Mekong Basin sediments (Noh et al., 2013; Gue dron et al., 2014). In the particular case of As, the positive correlation observed between ASSED and POCSED is unusual since As has been documented to be primarily controlled by sorption onto metal oxide surfaces in natural environments (e.g. Redman et al., 2002) although it has been reported that As was sequestered as organoarsenic complexes in organic rich sediments (Baruah et al., 2003). However, the co-precipitation of microbially synthetized arsenopyrites on organic matter surfaces or on the formation of organoarsenic complexes (Paikaray et al., 2005) can both explain the unusual observed correlation.

Finally, Metal $\mathrm{SED}_{\mathrm{S}}$ are positively correlated to Fe $\mathrm{SED}_{\mathrm{S}}$ and MnSED $_{\text {, }}$ with a significant correlation $(\mathrm{p}<0.01)$ between FeSED and the following MetalsED in the specific sequence:

$\mathrm{Pb}_{\mathrm{SED}}>\mathrm{Ni}_{\mathrm{SED}}>\mathrm{AsSED}_{\mathrm{SED}}>\mathrm{COSED}_{\mathrm{SED}}>\mathrm{Cu}_{\mathrm{SED}}>\mathrm{Al}_{\mathrm{SED}}>\mathrm{Hg}_{\mathrm{SED}}$

$>\mathrm{MnSED}_{\mathrm{S}}>\mathrm{Cr}_{\mathrm{SED}}>\mathrm{ZnSED}_{\mathrm{S}}>\mathrm{V}_{\mathrm{SED}}$ and between MnSED and the following Metal $>$ SED in the specific sequence: FeSED $>\mathrm{Pb}_{\mathrm{SED}}>$ COSED $>\mathrm{HgSED}_{\mathrm{S}}>\mathrm{Cu}_{\mathrm{SED}}>\mathrm{Al}_{\mathrm{SED}}>\mathrm{AsSED}_{\mathrm{S}}>\mathrm{Zn}_{\mathrm{SED}}>\mathrm{NiSED}$. $>\mathrm{Cr}_{\mathrm{SED}}>\mathrm{V}_{\mathrm{SED}}$. The sorption selectivity on most metal-oxide minerals determined by Schultz et al. (1987) follows the sequence $\mathrm{Cr} \leq \mathrm{Pb} \leq \mathrm{Cu}>\mathrm{Co} \leq \mathrm{Zn}>\mathrm{Ni} \leq \mathrm{Cd}$, with some distinct differences such as the preference of $\mathrm{MnO}_{2}$ for Co (Smith, 1999). The sequence based on Metal SED and FeSED/MnSED correlation in the Tien River surface sediments differs and exhibits a specific pattern, which could be related to the presence and characteristics of the surrounding acid sulfate soils (Minh et al., 1997). The oxidation of these soils causes metals to be redistributed from the "pyritic" and "organic" fractions to the "acid-soluble" fraction (Claff et al., 2011). Then, the subsequent acidification, due to exceedance of the acid neutralizing capacity of the soil, drives the release of metals to the "labile" fraction (Claff et al., 2011). Thus, the oxidation and acidification of sulfidic soil could lead to changes in metal mobility and consequently to metal sorption phases and distribution in the sediments. In the Tien River, the comparison of Metal ${ }_{S E D}$ with

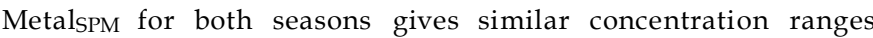
(Tables 3 and 6 ), except for $\mathrm{Cr}$ and $\mathrm{Pb}$ which present higher concentrations in sediments and SPM respectively. Such differences for $\mathrm{Cr}$ and $\mathrm{Pb}$ are likely related to a change in speciation and carrier phases in the sediment resulting in diagenetic processes (e.g. a drop in $\mathrm{pH}$ and $\mathrm{Eh}$ ). Because $\mathrm{Cr}$ is sensitive to redox states and oxygenation levels, the difference between measured CrSED and CrSPM could originate from differences between redox and oxygen values in the two compartments, even though they were not measured at the water-sediment interface. Unlike in the sediment no significant

Table 5

$\operatorname{LogKd}(\mathrm{Cr}, \mathrm{Co}, \mathrm{Ni}, \mathrm{Cu}, \mathrm{As}, \mathrm{Mo}, \mathrm{Pb})$ at each sampling site during both dry and rainy seasons. (n.d.: not determined).

\begin{tabular}{|c|c|c|c|c|c|c|c|c|}
\hline & Sites & $\log _{K D} \mathrm{Cr}$ & $\log _{\mathrm{KD}} \mathrm{Co}$ & $\log _{K D} N i$ & $\log _{K D} \mathrm{Cu}$ & $\log _{K D} A s$ & $\log _{K D} M o$ & $\log _{\mathrm{KD}} \mathrm{Pb}$ \\
\hline \multirow[t]{10}{*}{ March dry season } & MD-1 & 5.3 & 5.0 & 4.4 & 4.3 & n.d. & n.d. & 5.6 \\
\hline & MD-2 & 5.7 & 5.6 & 4.6 & n.d. & n.d. & n.d. & 5.7 \\
\hline & MD-3 & 5.8 & 5.5 & 4.6 & 4.4 & n.d. & n.d. & 6.1 \\
\hline & MD-4 & 5.8 & 5.5 & 4.7 & 4.9 & n.d. & n.d. & 5.1 \\
\hline & MD-5 & n.d. & 5.8 & 4.8 & 4.6 & n.d. & n.d. & 6.4 \\
\hline & MD-6 & 5.6 & 5.5 & 4.8 & 4.4 & n.d. & n.d. & 5.3 \\
\hline & MD-7 & n.d. & 5.5 & 4.7 & 4.4 & n.d. & n.d. & 5.7 \\
\hline & MD-8 & 5.4 & 5.6 & 4.7 & 4.4 & n.d. & n.d. & 5.5 \\
\hline & MD-9 & 5.8 & 5.8 & 4.9 & 4.4 & n.d. & n.d. & 6.0 \\
\hline & MD-10 & 5.5 & 5.7 & 4.6 & 4.3 & n.d. & n.d. & 5.9 \\
\hline \multirow[t]{5}{*}{ October rainy season } & $\mathrm{MD}-4$ & 5.6 & n.d. & n.d. & 4.2 & 4.4 & 3.6 & 4.6 \\
\hline & MD-5 & 6.1 & n.d. & n.d. & 4.6 & 4.4 & 3.0 & 5.5 \\
\hline & MD-6 & 5.0 & n.d. & n.d. & 4.6 & 4.5 & 3.7 & 6.3 \\
\hline & MD-7 & n.d. & n.d. & n.d. & 4.6 & 4.4 & 3.3 & 5.7 \\
\hline & MD-10 & n.d. & n.d. & n.d. & 4.1 & 4.0 & 3.3 & n.d. \\
\hline
\end{tabular}


Table 6

Measured particulate metal (VSED, CrSED, CoSED, Nised, CusED, ZnSED, Assed, Mosed, CdSED, Pbsed, Alsed, Fesed, Mnsed) and particulate organic carbon (POC) concentrations in surface sediment at each sampling site during both dry and rainy seasons. (n.d.: not determined).

\begin{tabular}{|c|c|c|c|c|c|c|c|c|c|c|c|c|c|c|c|c|}
\hline & Sites & $\mathrm{V}_{\mathrm{SED}}$ & $\mathrm{Cr}_{\mathrm{SED}}$ & Cosed & $\mathrm{Ni}_{\text {SED }}$ & $\mathrm{Cu}_{\mathrm{SED}}$ & $Z_{\mathrm{SED}}$ & AsSED & Mosed & $\mathrm{Cd}_{\mathrm{SED}}$ & $\mathrm{Pb}_{\mathrm{SED}}$ & $\mathrm{Hg}_{\text {SED }}$ & $\mathrm{Al}_{\mathrm{SED}}$ & $F_{\text {SED }}$ & \multicolumn{2}{|c|}{$\mathrm{Mn}_{\mathrm{SED}} \mathrm{POC}_{\mathrm{SEL}}$} \\
\hline \multirow[t]{10}{*}{ March dry season } & MD-1 & 110 & 71.4 & 16.7 & 37.0 & 36.2 & 171 & 19.0 & 0.57 & 0.31 & 30.4 & 0.087 & 79626 & 46884 & 1237 & 1.2 \\
\hline & MD-2 & 65 & 48.0 & 11.0 & 22.6 & 20.7 & 110 & 11.3 & 0.46 & 0.17 & 16.8 & 0.047 & 44947 & 28627 & 642 & 0.6 \\
\hline & MD-3 & 70 & 47.2 & 11.1 & 24.4 & 20.7 & 109 & 12.2 & 0.28 & 0.20 & 18.1 & 0.053 & 56738 & 31103 & 714 & 0.8 \\
\hline & MD-4 & 39 & 24.5 & 7.4 & 13.4 & 7.1 & 64 & 8.4 & 0.07 & 0.08 & 12.2 & 0.023 & 32926 & 19808 & 287 & 0.2 \\
\hline & MD-5 & 69 & 79.1 & 15.7 & 33.1 & 18.6 & 114 & 12.4 & 4.88 & 0.19 & 19.9 & 0.046 & 54501 & 34035 & 942 & 0.7 \\
\hline & MD-6 & 81 & 78.0 & 17.0 & 37.4 & 33.5 & 169 & 17.3 & 0.66 & 0.22 & 29.5 & 0.106 & 57177 & 45837 & 1132 & 1.2 \\
\hline & MD-7 & 98 & 76.6 & 16.6 & 39.7 & 28.9 & 155 & 18.8 & 0.88 & 0.14 & 25.7 & 0.074 & 70907 & 47073 & 1230 & 1.2 \\
\hline & MD-8 & 88 & 73.9 & 14.9 & 32.9 & 21.8 & 135 & 13.6 & 0.47 & 0.13 & 22.9 & 0.056 & 50708 & 38666 & 825 & 0.7 \\
\hline & MD-9 & 112 & 87.5 & 18.1 & 43.7 & 30.6 & 169 & 18.1 & 1.38 & 0.11 & 27.0 & 0.075 & 93633 & 49924 & 1172 & 1.1 \\
\hline & MD-10 & 68 & 48.8 & 15.3 & 27.5 & 17.7 & 117 & 14.9 & 0.52 & 0.11 & 17.7 & 0.066 & 52346 & 36196 & 827 & 1.4 \\
\hline \multirow[t]{5}{*}{ October rainy season } & $\mathrm{MD}-4$ & 161 & 83.8 & 21.8 & 37.7 & 34.2 & 256 & 19.1 & 0.62 & 0.24 & 29.6 & 0.089 & 79857 & 44667 & 1216 & 1.2 \\
\hline & MD-5 & 99 & 62.5 & 17.9 & 39.1 & 36.2 & 185 & 20.5 & 0.93 & 0.24 & 30.6 & 0.091 & 75141 & 46466 & 1328 & 1.5 \\
\hline & MD-6 & 99 & 66.7 & 16.3 & 35.2 & 29.1 & 169 & 18.7 & 0.66 & 0.22 & 27.3 & 0.071 & 61951 & 41198 & 1076 & 0.8 \\
\hline & MD-7 & 120 & 86.0 & 17.5 & 47.7 & 35.5 & 184 & 20.8 & 0.94 & 0.27 & 24.3 & 0.079 & n.d. & 41977 & 805 & 1.3 \\
\hline & MD-10 & 102 & 79.0 & 17.7 & 39.5 & 27.8 & 179 & 16.2 & 0.87 & 0.09 & 28.1 & 0.057 & 71390 & 45932 & 866 & 1.0 \\
\hline
\end{tabular}

Table 7

Pearson matrix correlation of particulate metal (Vsed, Crsed, Cosed, Nised, Cused, Znsed, Assed, Mosed, Cdsed, Pbsed, Alsed, Fesed, Mnsed; in mg kg ${ }^{-1}$ ) and POCsed content (\%) in sediment during both seasons.

\begin{tabular}{|c|c|c|c|c|c|c|c|c|c|c|c|c|c|c|c|}
\hline & $V_{S E D}$ & $\mathrm{Cr}_{\text {SED }}$ & Cosed & NisED & Cused & ZnSED & Assed & Mosed & CdsED & Pbsed & $\mathrm{Hg}_{\mathrm{SED}}$ & $\mathrm{Al}_{\mathrm{SED}}$ & Fesed & Mnsed & POCSED \\
\hline$v_{\mathrm{SED}}$ & 1 & & & & & & & & & & & & & & \\
\hline $\mathrm{Cr}_{\text {SED }}$ & $.755^{* *}$ & 1 & & & & & & & & & & & & & \\
\hline Cosed & $.874^{* *}$ & $.865^{* *}$ & 1 & & & & & & & & & & & & \\
\hline NisED & $.770^{* *}$ & $.919^{* *}$ & $.873^{* * *}$ & 1 & & & & & & & & & & & \\
\hline CusED & $.811^{* *}$ & $.737^{* *}$ & $.821^{* *}$ & $.862^{* * *}$ & 1 & & & & & & & & & & \\
\hline $\mathrm{Zn}_{\mathrm{SED}}$ & $.956^{* *}$ & $.749^{* *}$ & $.922^{* *}$ & $.784^{* * *}$ & $.875^{* *}$ & 1 & & & & & & & & & \\
\hline AsSED & $.807^{* *}$ & $.706^{* *}$ & $.851^{* *}$ & $.890^{* * *}$ & $.933^{* *}$ & $.850^{* *}$ & 1 & & & & & & & & \\
\hline Mosed & -.056 & .382 & .202 & .209 & -.065 & -.063 & -.060 & 1 & & & & & & & \\
\hline $\mathrm{Cd}_{\mathrm{SED}}$ & .495 & .330 & .405 & .402 & $.689^{* *}$ & $.517^{*}$ & $.567^{*}$ & .059 & 1 & & & & & & \\
\hline $\begin{array}{l}\text { PbsED } \\
\mathrm{Hg}_{\text {SED }}\end{array}$ & $\begin{array}{l}.776^{* *} \\
.668^{* *}\end{array}$ & $\begin{array}{l}.753^{* *} \\
.619^{*}\end{array}$ & $\begin{array}{l}.861^{* *} \\
.782^{* *}\end{array}$ & $\begin{array}{l}.822^{* * *} \\
.731^{* *}\end{array}$ & $\begin{array}{l}.925^{* *} \\
.903^{* *}\end{array}$ & $\begin{array}{l}.874^{* *} \\
.790^{* *}\end{array}$ & $\begin{array}{l}.871^{* *} \\
.862^{* *}\end{array}$ & $\begin{array}{l}-.010 \\
-.126\end{array}$ & $\begin{array}{l}.525^{*} \\
.620^{*}\end{array}$ & $\begin{array}{l}1 \\
.854^{* *}\end{array}$ & 1 & & & & \\
\hline $\begin{array}{l}\mathrm{Al}_{\text {SED }} \\
\mathrm{Fe} \mathrm{SED}\end{array}$ & $\begin{array}{l}.827^{* *} \\
.754^{* *}\end{array}$ & $\begin{array}{l}.739^{* *} \\
.826^{* *}\end{array}$ & $\begin{array}{l}.807^{* *} \\
.888^{* *}\end{array}$ & $\begin{array}{l}.866^{\text {** }} \\
.908^{\text {** }}\end{array}$ & $\begin{array}{l}.821^{* *} \\
.882^{* *}\end{array}$ & $\begin{array}{l}.785^{\text {** }} \\
.810^{* *}\end{array}$ & $\begin{array}{l}.835^{* *} \\
.890^{* *}\end{array}$ & $\begin{array}{l}.074 \\
.038\end{array}$ & $\begin{array}{l}.359 \\
.346\end{array}$ & $\begin{array}{l}.808^{\text {** }} \\
.931^{\text {** }}\end{array}$ & $\begin{array}{l}.660^{*} \\
.830^{* *}\end{array}$ & $\begin{array}{l}1 \\
.878^{* *}\end{array}$ & 1 & & \\
\hline MnSED & $.682^{* *}$ & $.692^{* *}$ & $.837^{* *}$ & $.748^{* *}$ & $.831^{* *}$ & $.756^{* *}$ & $.829^{* *}$ & .170 & .505 & $.887^{* *}$ & $.836^{* *}$ & $.830^{* * *}$ & $.893^{* *}$ & 1 & \\
\hline POC $_{\text {SED }}$ & $.596^{*}$ & $.531^{*}$ & $.756^{* *}$ & $.729^{\text {*** }}$ & $.759^{* *}$ & $.662^{* *}$ & $.837^{* *}$ & -.054 & .406 & $.666^{\text {** }}$ & $.828^{* *}$ & $.696^{* * *}$ & $.786^{\text {** }}$ & $.745^{\text {** }}$ & 1 \\
\hline
\end{tabular}

*Correlation is significant at the 0.05 level (2-tailed).

${ }^{* *}$ Correlation is significant at the 0.01 level (2-tailed).

correlation was observed between FesPM and CrSPM although Fe concentrations are in the same range in both compartments. The change of affinity with $\mathrm{Fe}$ should be emphasized during field studies and/or experiments to point out the role of redox processes on $\mathrm{Cr}$ partitioning. The observed lower PbSED concentrations when compared to Pbspm could be the result of intense sediment lixiviation by estuarine and marine waters leading to increasing $\mathrm{Pb}$ mobility from the sediment to the dissolved phase as it has been observed in the Yangtze River Estuary (Zhao et al., 2013). This hypothesis cannot be supported in the Tien River.

\subsection{Risk assessment of Tien River surface sediments}

To assess the degree of metal enrichment in the surface sediments of the Tien River we compared two geochemical indexes: the Enrichment Factor (EF) and the Geoaccumulation Index (Igeo) (see material and method 2.3.), calculated for each site and metal. Globally, the calculated EF at all sites (Table 8) evidences none to minor enrichment for $\mathrm{V}, \mathrm{Cr}, \mathrm{Co}, \mathrm{Ni}, \mathrm{Cu}, \mathrm{Mo}, \mathrm{Cd}, \mathrm{Pb}$ and $\mathrm{Hg}(\mathrm{EF}<1.5)$, moderate enrichment for $\mathrm{Zn}(3<\mathrm{EF}<5)$, and moderately severe to severe enrichment for As $(5<\mathrm{EF}<25)$. The calculated Igeo at all sites (Table 8) demonstrates uncontaminated sediment to minor contamination for $\mathrm{V}, \mathrm{Cr}, \mathrm{Co}, \mathrm{Ni}, \mathrm{Cu}, \mathrm{Mo}, \mathrm{Cd}, \mathrm{Pb}$ and $\mathrm{Hg}(\mathrm{Igeo}<1)$, moderate contaminated sediments for $\mathrm{Zn}(1<$ Igeo $<2)$, and moderate to strong contaminated sediment for As $(2<$ Igeo $<4)$.

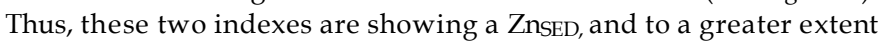
an AsSED enrichment or contamination issue in this environment. First of all, we would like to point out that the index conclusions strongly depend on the background values chosen, i.e. the UCC (Wedepohl, 1995) in the present study. In the case of the Mekong River watershed, the geology is diverse and rich making it difficult to get a proper background value. In the absence this background value from a sediment core, Wang et al. (2012b) defined a background value from a geometric means of a high number of samples from the Manwan Reservoir in the Upper Mekong River in China. However, this calculated background value presents high coefficient of variation and low representativity, which can be an issue if applying to the Mekong Delta, considering the distance between this reservoir and the Mekong Delta (up to 2,600 km) and the high number of confluent rivers with specific geological characteristics of the catchment area. Thus, we consider that the UCC is the most suitable background value for this environment. The conclusion of AsSED enrichment in the Tien River is coherent with the literature on As contamination in the Mekong Delta, characterized by high levels of As in groundwater and in sediment cores and also by a serious health risk to the local population (e.g. Berg et al., 2007; Buschmann et al., 2008; Hoang et al., 2010). Note that because of the poor $\mathrm{Zn}$ accuracy measurement and the consequences on $\mathrm{Zn}$ 
Table 8

Calculated EF and Igeo for surface sediment at each sampling site during both dry and rainy seasons. (n.d.: not determined).

\begin{tabular}{|c|c|c|c|c|c|c|c|c|c|c|c|c|}
\hline Enrichment Factor & & $\mathrm{EF}_{\mathrm{V}}$ & $\mathrm{EF}_{\mathrm{Cr}}$ & $\mathrm{EF}_{\mathrm{Co}}$ & $\mathrm{EF}_{\mathrm{Ni}}$ & $\mathrm{EF}_{\mathrm{cu}}$ & $\mathrm{EF}_{\mathrm{Zn}}$ & $\mathrm{EF}_{\mathrm{As}}$ & $\mathrm{EF}_{\mathrm{Mo}}$ & $\mathrm{EF}_{\mathrm{cd}}$ & $\mathrm{EFPb}$ & $\mathrm{EF}_{\mathrm{Hg}}$ \\
\hline \multirow[t]{10}{*}{ March dry season } & MD-1 & 2.0 & 2.0 & 1.4 & 1.9 & 2.5 & 3.2 & 9.2 & 0.4 & 3.0 & 1.7 & 1.5 \\
\hline & MD-2 & 2.1 & 2.4 & 1.6 & 2.1 & 2.5 & 3.6 & 9.8 & 0.6 & 2.8 & 1.7 & 1.5 \\
\hline & MD-3 & 1.8 & 1.8 & 1.3 & 1.8 & 2.0 & 2.9 & 8.3 & 0.3 & 2.7 & 1.5 & 1.3 \\
\hline & MD-4 & 1.7 & 1.6 & 1.5 & 1.7 & 1.2 & 2.9 & 9.9 & 0.1 & 1.9 & 1.7 & 0.9 \\
\hline & MD-5 & 1.8 & 3.2 & 1.9 & 2.5 & 1.9 & 3.1 & 8.8 & n.d. & 2.7 & 1.7 & 1.2 \\
\hline & MD-6 & 2.1 & 3.0 & 2.0 & 2.7 & 3.2 & 4.4 & 11.7 & 0.6 & 2.9 & 2.3 & 2.6 \\
\hline & MD-7 & 2.0 & 2.4 & 1.6 & 2.3 & 2.2 & 3.2 & 10.3 & 0.7 & 1.5 & 1.6 & 1.4 \\
\hline & MD-8 & 2.5 & 3.2 & 2.0 & 2.7 & 2.3 & 4.0 & 10.4 & 0.5 & 2.0 & 2.1 & 1.5 \\
\hline & MD-9 & 1.7 & 2.1 & 1.3 & 1.9 & 1.8 & 2.7 & 7.5 & 0.8 & 0.9 & 1.3 & 1.1 \\
\hline & MD-10 & 1.9 & 2.1 & 1.9 & 2.2 & 1.8 & 3.3 & 11.0 & 0.5 & 1.5 & 1.5 & 1.7 \\
\hline \multirow{5}{*}{ October rainy season } & MD-4 & 3.0 & 2.3 & 1.8 & 2.0 & 2.3 & 4.8 & 9.2 & 0.4 & 2.3 & 1.7 & 1.5 \\
\hline & MD-5 & 1.9 & 1.8 & 1.6 & 2.2 & 2.6 & 3.7 & 10.6 & 0.7 & 2.5 & 1.9 & 1.7 \\
\hline & $\begin{array}{l}\text { MD-5 } \\
\text { MD-6 }\end{array}$ & 2.3 & 2.4 & 1.8 & 2.4 & 2.5 & 4.1 & 11.7 & 0.6 & 2.7 & 2.0 & 1.6 \\
\hline & MD-7 & n.d. & n.d. & n.d. & n.d. & n.d. & n.d. & n.d. & n.d. & n.d. & n.d. & n.d. \\
\hline & MD-10 & 2.1 & 2.4 & 1.7 & 2.3 & 2.1 & 3.7 & 8.8 & 0.7 & 1.0 & 1.8 & 1.1 \\
\hline Igeo & & Igeov & $I g e o_{\mathrm{Cr}}$ & $\operatorname{IgeoCo}_{\mathrm{C}}$ & $I g e o \mathrm{Ni}$ & $I g e o_{\mathrm{cu}}$ & IgeoZn & $I g e o_{\mathrm{As}}$ & $I g e o \mathrm{Mo}$ & $I g e o_{\mathrm{cd}}$ & Igeopb & $I g e O \mathrm{Hg}$ \\
\hline \multirow[t]{10}{*}{ March dry season } & MD-1 & 0.5 & 0.4 & -0.1 & 0.4 & 0.8 & 1.1 & 2.7 & -1.9 & 1.0 & 0.3 & 0.0 \\
\hline & MD-2 & -0.3 & -0.1 & -0.7 & -0.3 & -0.1 & 0.5 & 1.9 & -2.2 & 0.1 & -0.6 & -0.8 \\
\hline & MD-3 & -0.2 & -0.2 & -0.6 & -0.2 & -0.1 & 0.5 & 2.0 & -2.9 & 0.4 & -0.5 & -0.7 \\
\hline & $\mathrm{MD}-4$ & -1.0 & -1.1 & -1.2 & -1.1 & -1.6 & -0.3 & 1.5 & -5.0 & -0.9 & -1.1 & -1.9 \\
\hline & MD-5 & -0.2 & 0.6 & -0.1 & 0.2 & -0.2 & 0.5 & 2.1 & n.d. & 0.3 & -0.4 & -0.9 \\
\hline & MD-6 & 0.0 & 0.6 & 0.0 & 0.4 & 0.6 & 1.1 & 2.5 & -1.7 & 0.5 & 0.2 & 0.3 \\
\hline & MD-7 & 0.3 & 0.5 & -0.1 & 0.5 & 0.4 & 1.0 & 2.6 & -1.3 & -0.1 & 0.0 & -0.2 \\
\hline & MD-8 & 0.1 & 0.5 & -0.2 & 0.2 & 0.0 & 0.8 & 2.2 & -2.2 & -0.2 & -0.2 & -0.6 \\
\hline & MD-9 & 0.5 & 0.7 & 0.1 & 0.6 & 0.5 & 1.1 & 2.6 & -0.6 & -0.4 & 0.1 & -0.2 \\
\hline & MD-10 & -0.2 & -0.1 & -0.2 & 0.0 & -0.3 & 0.6 & 2.3 & -2.0 & -0.5 & -0.5 & -0.4 \\
\hline \multirow[t]{5}{*}{ October rainy season } & MD-4 & 1.0 & 0.7 & 0.3 & 0.4 & 0.7 & 1.7 & 2.7 & -1.8 & 0.7 & 0.2 & 0.1 \\
\hline & MD-5 & 0.3 & 0.3 & 0.0 & 0.5 & 0.8 & 1.2 & 2.8 & -1.2 & 0.7 & 0.3 & 0.1 \\
\hline & MD-6 & 0.3 & 0.3 & -0.1 & 0.3 & 0.4 & 1.1 & 2.6 & -1.7 & 0.5 & 0.1 & -0.2 \\
\hline & MD-7 & 0.6 & 0.7 & 0.0 & 0.8 & 0.7 & 1.2 & 2.8 & -1.2 & 0.8 & -0.1 & -0.1 \\
\hline & MD-10 & 0.4 & 0.6 & 0.0 & 0.5 & 0.4 & 1.2 & 2.4 & $\begin{array}{l}-1.2 \\
-1.3\end{array}$ & -0.7 & 0.1 & -0.5 \\
\hline
\end{tabular}

concentration over-estimation, the observed ZnSED enrichment may be either over-estimated or may originate from the direct release of industrial and urban wastewater without prior treatment and from urban release such as street and construction dust, house roof made of zinc, or worn out tires.

According to the metal enrichment index results in the Tien River we assessed the ecotoxicological status of its sediments by comparing the measured concentrations with the commonly used

Table 9

Calculated sediment quality guidelines index for freshwater (TEC, PEC, m-PEC-q) and marine water (ERL, ERM, m-ERM-q) ecosystems for surface sediment at each sampling site during both dry and rainy seasons. $\mathrm{N}$ is the number of samples comprised between TEC and PEC values and between ERL and ERM values for each metal.

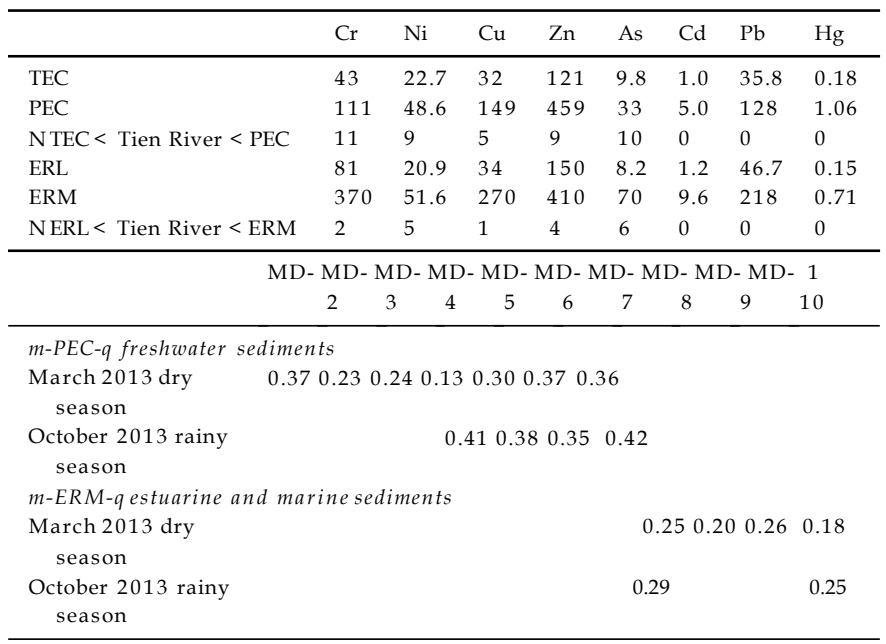

SQG values for freshwater sediment (i.e MD-1 to MD-7) using TEC, PEC and m-ERM-q indexes and for marine sediments (i.e. MD-7 to MD-10) using ERL, ERM and m-ERM-q indexes (Table 9). Both freshwater and marine sediments exhibit CdSED, PbSED, HgSED concentration ranges below which adverse effects are not expected to occur (lower than TEC and ERL) while $\mathrm{Cr}_{\mathrm{SED}}$, NisED, $\mathrm{Cu}_{\mathrm{SED}}$, Zn $\mathrm{n}_{\mathrm{SED}}$, ASSED exhibit a concentration range above which adverse effects are expected to occur (Table 9). The possible adverse effects of toxic mixtures $(\mathrm{Cr}, \mathrm{Ni}, \mathrm{Cu}, \mathrm{Zn}, \mathrm{As}, \mathrm{Cd}, \mathrm{Pb}, \mathrm{Hg})$ evaluated by the calculation of the m-PEC-q and m-ERM-q for freshwater and marine sediments respectively (Table 9), predict an absence of toxicity in the surface freshwater sediments and possible low to medium ecotoxicological potential effects in the estuarine-marine sediments of the Tien River. Because of possible $\mathrm{Zn}$ concentration over-estimation, $\mathrm{m}$ PEC-q and m-ERM-q were calculated excluding ZnSED. The two calculations present similar index values (data not shown) suggesting the low contribution of $\mathrm{Zn}$ to possible adverse toxic effects These results support the idea that Mekong River sediments present a low risk to benthic organisms according to metal contamination. However, assumptions regarding ecotoxicological effects should be investigated in further studies combining metal accumulation in sediments and benthic organisms.

\section{Conclusions}

Despite the development of intense agricultural and aquaculture activity, and of rapid urban growth illustrated by localised high nutrient and organic carbon levels, the Tien River remains in a state of good quality regarding trace metal contamination. Trace metal distributions vary spatially and the metal partitioning appears to be highly dynamic in the salinity gradient of the Mekong Delta. Although the ecotoxicological indexes demonstrated a low to medium contamination of the surface sediments, direct accumulation 
measurement in benthic organisms are required to assess the metal risk in biota.

\section{Acknowledgments}

This study has been conducted under the framework of CARERESCIF initiative. The authors would like to thank the students for their help during sampling and the anonymous reviewers for their comments. This study was funded by incentive grants from the French National Research Institute for Sustainable Development IRD, by grants from the Vietnam National University (grant number B2016-20-05), and by grants from Re' gion Rho ne Alpes COOPERA "Take Care".

\section{References}

Anonymous, 23 October, 2000. Directive of the European Parliament and of the Council $(2000 / 60 / E C)$ Establishing a Framework of Community Action in the Field of Water Policy.

APHA, 1995. Standard Methods for the Examination of Water and Wastewater. American Public Health Association, Washington, DC.

Apitz, S.E., Power, E.A., 2002. From risk assessment to sediment management: an international perspective. J. Soil Sed. 2, $61 \mathbf{e} \underline{66}$.

Baruah, M.K., Kotoky, P., Baruah, J., Borah, G.C., Bora, P.K., 2003. Arsenic association and distribution in carbonaceous materials in northeastern India. Curr. Sci. India $85,2 \mathbf{e} 25$

Berg, M., Stengel, C., Trang, P.T.K., Pham, H.V., Sampson, M.L., Leng, M., Samreth, S. Fredericks, D., 2007. Magnitude of arsenic pollution in the Mekong and Red River Deltas- Cambodia and Vietnam. Sci. Total. Environ. 372, $413 \mathbf{e} 425$.

Birth, G.A., 2003. Ascheme for assessing human impacts on coastal aquatic environments using sediments. In: Woodcoffe, C.D., Furness, R.A. (Eds.), Coastal GIS 2003. Wollongong University Papers in Centre for Maritime Policy, 14, Australia.

Buschmann, I., Berg, M., Stengel, C., Winkel, L., Sampson, M.L., Pham, T.K.T., Pham, H.V., 2008. Contamination of drinking water resources in the Mekong delta floodplains: arsenic and other trace metals pose serious health risk to population. Environ. Intern 34, $756 \mathbf{e} 764$.

Campbell, I.C., 2012. Biodiversity in the Mekong delta. In: Renaud, F.G., Künzer, C. (Eds.), The Mekong Delta System: Interdisciplinary Analyses of a River Delta. Springer Environ Sci Engineer, pp. $293 \mathbf{e} 314$ (Chapter 11).

Cenci, R.M., Martin, J.M., 2004. Concentration and fate of trace metals in Mekong River Delta. Sci. Total. Environ. 332, $167 \mathbf{e} 182$.

Chapman, P.M., Wang, F., 2001. Assessing sediment contamination in estuaries. Environ. Toxicol. Chem. 20, 3 e 22.

Claff, S.R., Burton, E.D., Sullivan, L.A., Bush, R.T., 2011. Metal partitioning dynamics during the oxidation and acidification of sulfidic soil. Chem. Geol. 286, $146 \mathbf{e} 157$. Coynel, A., Seyler, P., Etcheber, H., Meybeck, M., Orange, D., 2005. Spatial and seasonal dynamics of total suspended sediment and organic carbon species in the Congo River. Glob. Biogeochem. Cycles 19, GB4019.

Dabrin, A., Scha $€$ fer, I., Blanc, G., Strady, E., Masson, M., Bossy, C., Castelle, S., Girardot, N., Coynel, A., 2009. Improving estuarine net flux estimates for dissolved cadmium export at the annual timescale: application to the Gironde Estuary. Estuar. Coast. Shelf. S. 84,429 e 439 .

Dalai, T.K., Nishimura, K., Nozaki, Y., 2005. Geochemistry of molybdenum in the Chao Phraya River Estuary, Thailand: role of suboxic diagenesis and porewater transport. Chem. Geol. 218, 189 e202.

Datta, D.K., Subramanian, V., 1998. Distribution and fractionation of heavy metals in the surface sediments of the Ganges-Brahmaputra-Meghna river system in the Bengal basin. Environ. Geol. 36, 93 e 101.

de Souza Machado, A.A., Spencer, K., Kloas, W., Toffolon, M., Zarfl, C., 2016. Metal fate and effects in estuaries: a review and conceptual model for better understanding of toxicity. Sci. Total. Environ. 541, $268 \mathbf{e} 281$.

Du Laing, G., De Vos, R., Vandescasteele, B., Lesage, E., Tack, F.M.G., Verloo, M.G., 2008. Effect of salinity on heavy metal mobility and availability in intertidal sediments of the Scheldt estuary. Estuar. Coast. Shelf S 77, $589 \mathbf{e} 602$.

Etcheber, H., Taillez, A., Abril, G., Garnier, J., Servais, P., Moatar, F., Commarieu, M.V., 2007. Particulate organic carbon in the estuarine turbidity maxima of the Gironde, Loire and Seine estuaries: origin and lability. Hydrobiology 588, $\underline{245} \mathbf{e} 259$.

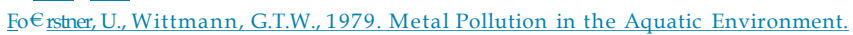
486 S., 102 Abb., 94 Tab. Berlin-Heidelberg-New York 1979. Springer-Verlag.

Gaillardet, I., Dupre', B., Alle 'gre, C.J., 1999. Geochemistry of large river suspended sediments: silicate weathering or crustal recycling? Geochim. Cosmochim. Acta 63, 4037e 4051

Gaillardet, J., Viers, J., Dupre', B., 2014. Trace Elements in river waters. In: Holland, H.D., Turekian, K.K. (Eds.), Treatise on Geochemistry, second ed., vol. 7. Oxford Elsevier, pp. 195 e 235 .

Garnier, J., Billen, G., Ne' mery, J., Sebilo, M., 2010. Transformations of nutrients (N, P. Si) in the turbidity maximum zone of the Seine estuary and export to the sea. Est. Coast. Shelf S 90,129 e 141.

Garnier, J., Lassaletta, L., Billen, G., Romero, E., Grizzetti, B., Ne' mery, I., Le, T.P.Q.,
Pistocchi, C., Aissa-Grouz, N., Luu, T.N.M., Vilmin, L., Dorioz, J.-M., 2015. Phosphorus budget in the water-agro-food system at nested scales in two contrasted regions of the world (ASEAN-8 and EU-27). Glob. Biogeochem. Cycles 29, $1348 \mathbf{e} 1368$

General Statistics Office of Vietnam GSO, 2016. Population and Employment, Statistical Yearbook of Vietnam 2015. Statistical Publishing House, Hanoi, pp. $\underline{57} \mathbf{e} 155$.

Giang, C.N.D., Sebesvari, Z., Renaud, F.G., Rosendahl, I., Minh, Q.H., Amelung, W., 2015. Occurrence and dissipation of the antibiotics sulfamethoxazole, sulfadiazine, trimethoprim, and enrofloxacin in the Mekong Delta, Vietnam. PLoS One 10,7 .

Gue dron, S., Grangeon, S., Lanson, B., Grimaldi, M., 2009. Mercury speciation in a tropical soil association; consequence of gold mining on $\mathrm{Hg}$ distribution in French Guiana. Geoderma 153, 331 e346.

Gue dron, S., Tisserand, D., Garambois, S., Spadini, L., Molton, F., Bounvilay, B., 2014 Baseline investigation of (methyl)mercury in waters, soils, sediments and key foodstuffs in the lower Mekong Basin: the rapidly developing city of Vientiane (Lao PDR). J. Geochem Explor 143, $96 \mathbf{e} 102$.

Hoang, T.H., Bang, S., Kim, K.W., Nguyen, M.H., Dang, D.M., 2010. Arsenic in groundwater and sediment in the Mekong River delta, Vietnam. Environ. Poll. $158,2648 \mathbf{e} 2658$

Jung, H.S., Lim, D., Xu, Z., Kang, J.H., 2014. Quantitative compensation of grain-size effects in elemental concentration: a Korean coastal sediments case study. Estuar. Coast. Shelf S 151, $69 \mathbf{e} 77$.

Kao, S.J., Liu, K.K., 1997. Loads of dissolved and nonfossil particulate organic carbon from an Oceania small river (Lanyang Hsi) in Taiwan. Biogeochem 39, 255 e 269. Kraepiel, A.M.L., Chiffoleau, J.F., Martin, J.M., Morel, F.M.M., 1997. Geochemistry of trace metals in the Gironde Estuary. Geochim. Cosmochim. Acta 61, 1421e1436.

Kummu, M., Lu, X.X., Wang, J.J., Varis, O., 2010. Basin-wide sediment trapping efficiency of emerging reservoirs along the Mekong. Geomorph 119, 181e197.

Lefebvre, J.P., Ouillon, S., Vinh, V.D., Arfi, R., Panche', J.Y., Mari, X., Thuoc, C.V. Torre ton, J.P., 2012. Seasonal variability of cohesive sediment aggregation in the Bach Dang-Cam Estuary, Haiphong (Vietnam). Geo-Mar. Lett. 32, $103 \mathbf{e} 121$.

Li, X., Yang, L., Yan, W., 2011. Model analysis of dissolved inorganic phosphorus exports from the Yangtze river to the estuary. Nutr. Cycl. Agroecosyst 90 $157 \mathbf{e} 170$.

Li, S., Bush, R, 2015. Rising flux of nutrients (C, N,P and Si) in the lower Mekong River. J. Hydrol. 530, $447 \mathbf{e} 461$

Liss, P.S., 1976. Conservative and non-conservative behavior of dissolved constituents during estuarine mixing. In: Burton, I.D., Liss, P.S. (Eds.), Estuarine Chemistry. Academic Press, London, pp. 93 e 130.

Loisel, H., Mangin, A., Vantrepotte, V., Dessailly, D., Dinh, D.N., Garnesson, P. Ouillon, S., Lefebvre, J.-P., Me' riaux, X., Phan, T.M., 2014. Variability of suspended particulate matter concentration in coastal waters under the Mekong's influence from ocean color (MERIS) remote sensing over the last decade. Rem. Sens, Environ. 150, $218 \mathbf{e} 230$

Long, E.R., Field, L.J., MacDonald, D.D., 1998. Predicting toxicity in marine sediments with numerical sediment quality guidelines. Environ. Toxicol. Chem. 17, $\underline{714} \mathbf{e} 727$.

Long, E.R., MacDonald, D.D., Smith, S.L., Calder, F.D., 1995. Incidence of adverse biological effects within ranges of chemical concentrations in marine and estuarine sediments. Environ. Manag. 19, $81 \mathbf{e} 97$.

Loring, D.H., 1991. Normalization of heavy-metal data from estuarine and coastal sediments. ICES J. Mar. Sci. 48, 101e115.

MacDonald, D.D., Ingersoll, C.G., Berger, T.A., 2000. Development and evaluation of consensus-based sediment quality guidelines for freshwater ecosystems. Arch. Environ. Contam. Toxicol. 39, 20 31.

Milliman, J.D., Meade, R.H., 1983. World-wide delivery of river sediment to the oceans. J. Geol. $91,1 \mathbf{e} 21$.

Milliman, J.D., Ren, M.E., 1995. River Flux to the Sea, Impact of Human Intervention on River Systems and Adjacent Coastal Areas. Impact on Coastal Habitation. CRC Press, pp. 57 e 83 .

Millward, G.E., Liu, Y.P., 2003. Modelling metal desorption kinetics in estuaries. Sci. Total. Environ. $314,613 \mathbf{e} 623$

Minh, L.Q., Tuong, T.P., van Mensvoort, M.E.F., Bouma, I., 1997. Contamination of surface water as affected by land use in acid sulfate soils in the Mekong River Delta, Vietnam. Agricul. Ecosyst. Environ. 61, 19e27.

Müller, G. 1979. Schwermetalle in den Sedimenten des Rheins e Vera $€$ nderungen seit 1971. Umschau 79, $778 \mathbf{e} 783$.

Murphy, J., Riley, J.P., 1962. Amodified single solution method for the determination of phosphate in natural waters. Anal. Chim. Acta 27,31e 36 .

Nguyen, V.L., Ta, T.K.O., Tateishi, M., 2000. Late Holocene depositional environments and coastal evolution of the Mekong River Delta, Southern Vietnam. J. Asian Earth Sci. 18, 27 e39.

Noh, S., Choi, M., Kim, E., Nguyen, P.D., Bui, X.T., Nguyen, T.V.H., Sthiannopkao, S., Han, S., 2013. Influence of salinity intrusion on the speciation and partitioning of mercury in the Mekong River Delta. Geochim. Cosmochim. Acta 106, 379 e 390 .

Nozaki, Y., 2001. Elemental distribution: overview. In: Steele, J.H., Thorpe, S.A., Turekian, K.K. (Eds.), Encyclopedia of Ocean Sciences, vol. 2. Academic Press, London, pp. 840 e 845

Paikaray, S., Banerjee, S., Mukherii, S., 2005. Sorption of arsenic onto Vindhyan shales: role of pyrite and organic carbon. Curr. Sci. India 10, $1580 \mathbf{e} 1585$.

Redman, A.D., Macalady, D.L., Ahmann, D., 2002. Natural organic matter affects arsenic speciation and sorption onto hematite. Environ. Sci. Technol. 36 
$\underline{2889} \mathbf{e} \underline{2896}$.

Renaud, F.G., Künzer, C., 2012. Introduction. In: Renaud, F.G., Künzer, C. (Eds.), The Mekong Delta System: Interdisciplinary Analyses of a River Delta, pp. 3 e6 Springer Environ Sci Engineer.

Schultz, M.F., Benjamin, M.M., Ferguson, J.F., 1987. Adsorption and desorption of metals on ferrihydrite: reversibility of the reaction and sorption properties of the regenerated solid. Environ. Sci. Technol. 21, $863 \mathbf{e} 869$.

Smith, K.S. 1999. Metal sorption on mineral surfaces: an overview with examples relating to mineral deposits. In reviews in Economic geology Vol 6A, the environmental geochemistry of mineral deposits, Eds Society of Economic Geologists Inc. (ISSN 0741e0123).

Statham, P.J., 2012. Nutrients in estuaries- an overview and the potential impacts of climate change. Sci. Total. Environ. 434, $213 \mathbf{e} 227$.

Strady, E., Blanc, G., Scha $€$ fer, J., Coynel, A., Dabrin, A., 2009. Dissolved uranium, vanadium and molybdenum behaviours during contrasting freshwater discharges in the Gironde Estuary (SW France). Estuar. Coast. Shelf S 83, 550 e 560.

Strady, E., Dang, V.B.H., Ne' mery, I., Gue' dron, S., Dinh, O.T., Denis, H., Nguyen, P.D. 2017. Baseline seasonal investigation of nutrients and trace metals in surface waters and sediments along the Saigon River basin impacted by the megacity of Ho Chi Minh (Vietnam). Environ. Sci. Poll. Res. 24,3226e 3243.

Toan, P.V., Sebesvari, Z., Bl€ asing, M., Rosendahl, I., Renaud, F.G., 2013. Pesticide management and their residues in sediments and surface and drinking water in the Mekong Delta. Vietnam. Sci. Total Environ. 452, $28 \mathbf{e} 39$.

Trinh, A.D., Meysman, F., Rochelle-Newall, E., Bonnet, M.P., 2012. Quantification of sediment-water interactions in a polluted tropical river through biogeochemical modeling. Glob. Biogeochem. Cycles 26, GB3010.

Turner, A., Millward, G.E., Bale, A.J., Morris, A.W., 1993. Application of the Kd concept to the study of trace metal removal and desorption during estuarine mixing. Estuar. Coast. Shelf S 36, 1 e 13 .

Viers, I., Dupré, B., Gaillardet, I., 2009. Chemical composition of suspended sediments in World Rivers: new insights from a new database. Sci. Total. Environ. $407,853 \mathbf{e} 868$

Waibel, G., Benedikter, S., Reis, N., Genschick, S., Nguyen, L., Huu, P.C., Be, T.T., 2012. Water governance under renovation? Concepts and practices of IWRM in the Mekong Delta, Vietnam. In: Renaud, F.G., Künzer, C. (Eds.), The Mekong Delta System: Interdisciplinary Analyses of a River Delta, pp. 167e200. Springer Environ Sci Engineer, (Chapter 6).

Wang, D., Lin, W.F., Yang, X.Q., Zhai, W.D., Dai, M.H., Chen, C.T.A., 2012a. Occurrences of dissolved trace metals ( $\mathrm{Cu}, \mathrm{Cd}$, and $\mathrm{Mn}$ ) in the Pearl River Estuary (China), a large river-groundwater-estuary system. Cont. Shelf Res. 50, 54 e 63.

Wang, C., Liu, S., Zhao, Q., Deng, L., Dong, S., 2012b. Spatial variation and contamination assessment of heavy metals in sediments in the Manwan Reservoir Lancang River. Ecotox. Environ. Saf. 82, 32 e 39.
Wang, H., Wang, J., Liu, R., Yu, W., Shen, Z., 2015. Spatial variation, environmenta risk and biological hazard assessment of heavy metals in surface sediments of the Yangtze River estuary. Mar. Pollut. Bull. 15, 250 e 258.

Wang, D., Xia, W., Lu, S., Wang, G., Liu, Q., Moore, W.S., Chen, C.T.A., 2016a. The nonconservative property of dissolved molybdenum in the western Taiwan Strait: relevance of submarine groundwater discharges and biological utilization. Geochem. Geophys. Geosyst 17, $28 \mathbf{e} \underline{43}$

Wang, Y., Liu, R.H., Zhang, Y.Q., Cui, X.Q., Tang, A.K., Zhang, L.J., 2016b. Transport of heavy metals in the Huanghe River estuary, China. Environ. Earth Sci. 75, 288. Wang, Y., Ling, M., Liu, R.H., Yu, P., Tang, A.K.K., Luo, X.X., Ma, Q., 2017. Distribution and source identification of trace metals in the sediment of Yellow River Es- tuary and the adjacent Laizhou Bay. Phys. Chem. Earth. http://dx.doi.org/ 10.1016/j.pce.2017.02.002.

Wedepohl, H., 1995. The composition of the continental crust. Geochim.Cosmochim. Acta 59, 1217e 1232

Wen, L.S., Jiann, K.T., Santschi, P.H., 2006. Physicochemical speciation of bioactive trace metals $(\mathrm{Cd}, \mathrm{Cu}, \mathrm{Fe}, \mathrm{Ni})$ in the oligotrophic South China Sea. Mar. Chem. 101 $\underline{104} \mathbf{e} 129$.

Wilbers, G.J., Becker, M., Nga, L.T., Sebesvari, Z., Renaud, F.G., 2014. Spatial and temporal variability of surface water pollution in the Mekong Delta, Vietnam. Sci. Total. Environ. 485,653 e 665 .

Windom, H., Smith, R., Niencheski, F., Alexander, C., 2000. Uranium in rivers and estuaries of globally diverse smaller watersheds. Mar. Chem. 68, $307 \mathbf{e} 321$.

World Bank, 2013. Vietnam Urban Wastewater Review Executive Summary. http:// wwW.worldbank.org/content/dam/Worldbank/document/EAP/Vietnam/vn urbanwastewater-summary-EN-final.pdf.

Xue, Z., Liu, J.P., Ge, Q., 2011. Changes in hydrology and sediment delivery of the Mekong River in the last 50 years: Connection to damming, monsoon, and ENSO. Earth Surf. Process. Landforms 36, $296 \mathbf{e} 308$.

Xue, Z., He, R., Liu, J.P., Warner, J.C., 2012. Modeling transport and deposition of the Mekong River sediment. Cont. Shelf Res. 37, 66 e 78 .

Yang, Z., Xia, X., Wang, Y., Ji, J., Wang, D., Hou, Q., Yu, T., 2014. Dissolved and particulate partitioning of trace elements and their spatialetemporal distribution in the Changjiang River. J. Geochem. Explor 145, 114e123.

Zhang, I., Liu, C.L., 2002. Riverine composition and estuarine geochemistry of par ticulate metals in China: weathering features, anthropogenic impact and chemical fluxes. Estuar. Coast. Shelf S. 54,1051e1070.

Zhang, D., Zhang, X., Tian, L., Ye, F., Huang, X., Zeng, Y., Fan, M., 2013. Seasonal and spatial dynamics of trace elements in water and sediment from Pearl River Estuary, South China. Environ. Earth Sci. 68, 1053 e1063.

Zhao, S., Feng, C.H., Wang, D.X., Liu, Y.Z., Shen, Z.Y., 2013. Salinity increases the mobility of $\mathrm{Cd}, \mathrm{Cu}, \mathrm{Mn}$, and $\mathrm{Pb}$ in the sediments of Yangtze Estuary: relative role of sediments' properties and metal speciation. Chemosphere 91, 977e 984 . 